\title{
A climosequence of chronosequences in southwestern Australia
}

\author{
B.L. TURNER ${ }^{\mathrm{a}, \mathrm{b}}$, P.E. HAYES ${ }^{\mathrm{b}}$, E. LALIBERTÉ ${ }^{\mathrm{c}, \mathrm{b}}$
}

${ }^{a}$ Smithsonian Tropical Research Institute, Apartado 0843-03092, Balboa, Ancon, Republic of Panama, ${ }^{\mathrm{b}}$ School of Biological Sciences, The University of Western Australia, 35 Stirling Highway, Crawley, Perth, WA 6009, Australia, and ${ }^{\mathrm{C}}$ Centre sur la Biodiversité, Institut de Recherche en Biologie Végétale, Département de Sciences Biologiques, Université de Montréal, 4101 Sherbrooke Est, Montréal H1X 2B2, Canada

Correspondence: B.L. Turner. E-mail: TurnerBL@si.edu

Running title: A climosequence of chronosequences in Australia

This is the author manuscript accepted for publication and has undergone full peer review but has not been through the copyediting, typesetting, pagination and proofreading process, which may lead to differences between this version and the Version of Record. Please cite this article as doi: $10.1111 /$ ejss. 12507

This article is protected by copyright. All rights reserved. 


\section{Summary}

To examine how climate affects soil development and nutrient availability over long timescales, we studied a series of four long-term chronosequences along a climate gradient in southwestern Australia. Annual rainfall ranged from $533 \mathrm{~mm}$ to $1185 \mathrm{~mm}$ (water balance from $-900 \mathrm{~mm}$ to $+52 \mathrm{~mm}$ ) and each chronosequence included Holocene (d6.5 ka), Middle Pleistocene (120-500 ka) and Early Pleistocene ( 2000 ka) dunes. Vegetation changed markedly along the climosequence from shrubland at the driest site to Eucalyptus forest at the wettest. Soil pH was similar in the youngest soil of each chronosequence, although the carbonate and $\mathrm{P}$ content of the parent sand declined from dry to wet along the climosequence, presumably linked to variation in offshore productivity. Despite this, soil development and associated nutrient status followed remarkably consistent patterns along the four chronosequences. Pedogenesis involved decalcification and secondary carbonate precipitation in Holocene soil and leaching of iron oxides from Middle Pleistocene soils, leading ultimately to bleached quartz sands in the oldest soil. Along all chronosequences soil $\mathrm{pH}$ and total $\mathrm{P}$ declined, whereas $\mathrm{C}: \mathrm{P}$ and $\mathrm{N}: \mathrm{P}$ ratios increased, which is consistent with the predicted change from $\mathrm{N}$ to $\mathrm{P}$ limitation of vegetation during ecosystem development. The expected unimodal pattern of leaf area index was most pronounced along wetter chronosequences, suggesting an effect of climate on the expression of retrogression. The four chronosequences do not appear to span a pedogenic climate threshold, defined as an abrupt change in soil properties across a relatively small change in climate, because exchangeable phosphate and base cations declined consistently during long-term pedogenesis. However, the proportion of

This article is protected by copyright. All rights reserved. 
total $\mathrm{P}$ in organic form was greater along wetter chronosequences. We conclude that soil and nutrient availability on the coastal sand plains of southwestern Australia change consistently during long-term pedogenesis, despite marked variation in modern vegetation and climate. The four chronosequences provide a rare soil-age $\times$ climate framework within which to study long-term ecosystem development.

Keywords: retrogression, phosphorus, nitrogen, pedogenesis, ecosystem development

\section{Highlights}

- We describe four long-term coastal dune chronosequences spanning a climate gradient in a global biodiversity hotspot.

- Pedogenesis involves depletion of phosphorus and cations linked to decalcification and subsequent podsolization.

- Climate has relatively little effect on patterns of nutrient availability during ecosystem development along the climosequence.

- The age by climate framework enables study of effect of edaphic change on above and below ground communities.

This article is protected by copyright. All rights reserved. 


\section{Introduction}

Pedogenesis over thousands to millions of years involves marked changes in nutrient availability (Vitousek, 2004). In particular, nitrogen (N) availability increases in the early stages of ecosystem development through biological $\mathrm{N}$ fixation, whereas phosphorus $(\mathrm{P})$ availability declines continuously as $\mathrm{P}$ is lost by leaching at a greater rate than it is replenished by weathering or atmospheric inputs (Walker \& Syers, 1976). This causes a longterm change from $\mathrm{N}$ to $\mathrm{P}$ limitation of plant biomass and productivity (Vitousek \& Farrington, 1997; Wardle et al., 2004; Laliberté et al., 2012), which is reflected in marked changes in the diversity and function of plant and microbial communities (Williamson et al., 2005; Jangid et al., 2013; Laliberté et al., 2013; Zemunik et al., 2015).

Rates of pedogenesis and nutrient depletion are affected markedly by climate (Chadwick \& Chorover, 2001; Selmants \& Hart, 2010; Feng et al., 2016). Assuming other soil-forming factors are held constant (i.e. topography, parent material and vegetation), wetter sites are expected to lose rock-derived nutrients at a greater rate than comparable drier sites because of accelerated weathering and greater leaching losses. However, vegetation typically co-varies with climate and might mitigate nutrient loss. For example, wetter sites tend to support more plant biomass than drier sites, which retains nutrients in the system and reduces the rate of nutrient loss by leaching when precipitation is in balance with potential evapotranspiration (Porder \& Chadwick, 2009). In contrast, arid ecosystems lose nutrients more slowly with less leaching, but have a limited potential to retain nutrients over long timescales because they 
support little plant biomass. In other words, plants might be able to influence the rate of nutrient loss during pedogenesis depending on the extent to which they retain nutrients in the plant-soil system, which itself depends on climate (Porder \& Chadwick, 2009).

The conceptual model of the effects of climate on pedogenesis described above has been tested only once (Porder \& Chadwick, 2009), despite its potential importance for our understanding of terrestrial nutrient cycling. This is because doing so requires multiple longterm soil chronosequences that are similar in terms of parent material, topography and time, yet differ in terms of potential evapotranspiration, precipitation and water balance. Model systems that meet these strict requirements are exceedingly rare, and so far only the wellstudied Hawaiian Island sequence has been suitable. Porder \& Chadwick (2009) studied three basalt lava flows on Hawaii that ranged from 10000 to 350000 years old, with annual precipitation from 500 to $2500 \mathrm{~mm}$. At relatively dry sites $(<750 \mathrm{~mm}$ annual rainfall) where evapotranspiration exceeded precipitation, plants slowed nutrient loss but the effect was small because there was little plant biomass. At intermediate rainfall sites $(750-1400 \mathrm{~mm})$ where potential evapotranspiration exceeded precipitation (i.e. negative water balance), plant uplift of nutrients enriched the soil surface with $P$ for at least 350000 years, effectively compensating for leaching losses. In contrast, at the wettest sites ( $>1500 \mathrm{~mm}$ annual rainfall) where precipitation exceeded evapotranspiration (i.e. positive water balance), leaching losses overwhelmed the capacity of plants to retain nutrients after 350000 years of pedogenesis, despite greater biomass. On much older soil (approximately 4 million years old) this effect of high rainfall occurred above $900 \mathrm{~mm}$ of annual rainfall (compared to $1500 \mathrm{~mm}$ on younger 
soil). This presumably reflects long-term depletion of $\mathrm{P}$, reduced productivity and therefore a reduced capacity of the ecosystem to retain nutrients against leaching losses (Vitousek \& Chadwick, 2013). The effect of plants on nutrient retention therefore appears to be strongest where potential evapotranspiration is roughly in balance with precipitation, although this can be overridden on strongly weathered soil when extreme P limitation reduces the capacity of plants to retain nutrients in the ecosystem.

The rainfall zones for P dynamics described by Porder \& Chadwick (2009) reflect the balance between precipitation and evapotranspiration, and correspond to 'soil process domains' (Vitousek \& Chadwick, 2013). These are defined as climate zones within which the soil appears to change relatively little across a broad range of rainfall. The domains are separated by pedogenic thresholds where soil properties vary abruptly across a relatively small range of rainfall (Chadwick \& Chorover, 2001). For basaltic soil on Hawaii subjected to about 150 000 years of pedogenesis, the process domains correspond to soil where: (i) evapotranspiration exceeds precipitation and carbonate accumulation dominates pedogenesis (low rainfall $<700 \mathrm{~mm}$ ), (ii) evapotranspiration is slightly greater than precipitation (700 to $1500 \mathrm{~mm}$ ) and plant uplift and retention of nutrients can compensate for leaching losses, (iii) precipitation exceeds evapotranspiration $(1500$ to $2500 \mathrm{~mm}$ ) and pedogenesis is dominated by the accumulation of metal oxides (Chadwick et al., 2003) and (iv) saturation causes iron to be solubilized and lost by reduction and leaching ( $>2500 \mathrm{~mm}$, a very wet domain) (Chadwick \& Chorover, 2001; Vitousek \& Chadwick, 2013). Above the threshold where precipitation exceeds evapotranspiration, the soil $\mathrm{pH}$, base cations and base saturation 
decrease, and exchangeable Al increases (Chadwick et al., 2003). These changes are linked to the depletion of primary minerals and leaching at a greater rate than they are replenished by weathering. It is unknown whether these pedogenic domains and thresholds apply more broadly outside Hawaii.

To investigate how climate influences pedogenesis and nutrient availability during long-term ecosystem development, we studied a series of four long-term (Early Pleistocene, approximately 2 million years) chronosequences along a rainfall gradient in southwestern Australia. Our recent study of soil development along the Jurien Bay chronosequence corresponds to the driest chronosequence in the present study (Turner \& Laliberté, 2015). It shows a characteristic pattern of soil development with decalcification of young carbonaterich dunes, formation of a petrocalcic horizon and leaching of iron oxide coatings from sand grains leaving bleached quartz sands many metres deep. These changes correspond with marked depletion of soil $\mathrm{P}$ and other nutrients, leading to some of the most infertile soil in the world on the oldest dunes. We extended our research at Jurien Bay to similar coastal dune deposits that extend hundreds of kilometres south along a strong climate gradient, enabling us to identify three additional long-term soil chronosequences with dunes of similar age but contrasting water balance. Our aim was to use this climosequence of chronosequences along the coast of southwestern Australia to examine how climate influences soil development and nutrient availability during long-term pedogenesis.

This article is protected by copyright. All rights reserved. 


\section{Materials and methods}

Regional overview and description of the chronosequences

A series of dune deposits parallel to the coast of southwestern Australia extends for approximately $400 \mathrm{~km}$ from Geraldton $\left(28.7774^{\circ} \mathrm{S}, 114.6150^{\circ} \mathrm{E}\right)$ in the north to Dunsborough $\left(33.6082^{\circ} \mathrm{S}, 115.0940^{\circ} \mathrm{E}\right)$ in the south (Figure 1) along the Swan Coastal Plain. The dunes were formed by periodic interglacial sea-level high-stands since the Early Pleistocene or Late Pliocene (i.e. 2.59 million years ago) (Kendrick et al., 1991). An additional area of dunes along the southern coastline near Pemberton $\left(34.4400^{\circ} \mathrm{S}, 116.0500^{\circ}\right.$ E), the Scott Coastal Plain, is assumed to correspond to the main dune deposits on the Swan Coastal Plain (Playford et al., 1976). The dunes and their associated soil types are grouped into three main units according to the underlying parent sand deposits (McArthur \& Bettenay, 1974; Playford et al., 1976). The Quindalup dunes are of Holocene age (up to 6500 years old), the Spearwood dunes are of Middle Pleistocene age (120 000 to 500000 years old), and the Bassendean dunes are Early Pleistocene (approximately 2 million years old). Geologically, the three dune systems correspond with the Safety Bay Sand, the Tamala Limestone, and the Bassendean Sand, respectively (Playford et al., 1976).

The Jurien Bay chronosequence is $200 \mathrm{~km}$ north of Perth (Figure 1, 2a) (Laliberté et al., 2012; Turner \& Laliberté, 2015). We now identify three additional chronosequences spanning a strong climate gradient along the coastline. These chronosequences on the Swan

This article is protected by copyright. All rights reserved. 
Coastal Plain are near Guilderton, approximately $75 \mathrm{~km}$ north of Perth (Figure $2 \mathrm{~b}$ ) and Yalgorup National Park, approximately $100 \mathrm{~km}$ south of Perth (Figure 2c). The chronosequence on the Scott Coastal Plain is at Warren Beach, in the D'Entrecasteaux National Park south of Pemberton and approximately $300 \mathrm{~km}$ south of Perth (Figure 2d).

\begin{abstract}
Along each of the three new chronosequences we delineated six to seven chronosequence stages: three Holocene (stages 1-3), three Middle Pleistocene (stages 4, 5, or 5a,b) and one Early Pleistocene (stage 6). In the three drier chronosequences on the Swan Coastal Plain (Jurien Bay, Guilderton, Yalgorup) these stages correspond to the Quindalup (Holocene), Spearwood (Middle Pleistocene) and Bassendean (Early Pleistocene) dunes (Figure 2a-c) described by McArthur (2004). For the Warren chronosequence on the Scott Coastal Plain, the first six stages are classified as Meerup sand or podzols (Figure 2d), whereas the oldest stage is mapped as the Cleave series (Purdie et al., 2004).
\end{abstract}

The precise ages of dune formation are not known for any of the chronosequence stages, but evidence indicates that the chronology ranges from the Holocene to the Early Pleistocene (see Turner \& Laliberté 2015 for a review). We assume that the broad chronology of dune formation and relative spatial configuration of dunes are consistent along the entire Swan Coastal Plain (Playford et al., 1976; McArthur, 2004). We also assume that the chronology of the Swan Coastal Plain is comparable to the main stages of dune formation along the Warren chronosequence on the Scott Coastal Plain (Playford et al., 1976), given that the formation of the main coastal dunes in the region relates to sea levels during interglacial periods

This article is protected by copyright. All rights reserved. 
throughout the Pleistocene (Kendrick et al., 1991). Thus, time is constrained only within the limits of our broad estimates about the times of dune formation.

\section{Climate along the chronosequences}

Precipitation, potential evapotranspiration and temperature are plotted in Figure 1, and the data for the four chronosequences are given in Table 1. Mean annual rainfall increases from $533 \mathrm{~mm}$ at Jurien Bay in the north to $1185 \mathrm{~mm}$ at Warren in the south. The dry season, defined as the number of months with $<30 \mathrm{~mm}$ of rainfall, varies from two months at Warren Beach to seven months at Jurien Bay. Mean annual temperature varies from $15.2^{\circ} \mathrm{C}$ at Warren in the south to $19.0^{\circ} \mathrm{C}$ at Jurien Bay in the north. Mean monthly minimum temperatures occur in July $\left(10.1^{\circ} \mathrm{C}\right.$ at Warren to $13.1^{\circ} \mathrm{C}$ at Jurien Bay) and mean monthly maximum temperatures occur in January or February $\left(20.3^{\circ} \mathrm{C}\right.$ at Warren and $25.6^{\circ} \mathrm{C}$ at Guilderton). Annual potential evapotranspiration ranges from $1133 \mathrm{~mm}$ at Warren Beach to $1433 \mathrm{~mm}$ at Jurien Bay, also reflected in water balances that range from $-900 \mathrm{~mm}$ at Jurien Bay to +52 $\mathrm{mm}$ at Warren.

There is little information on paleoclimate for the four sequences. Evidence suggests a trend of increasing aridity in central and Western Australia beginning in the Miocene (e.g. Fujioka et al., 2009) or perhaps the Quaternary (e.g. Zheng et al., 1998). However, the Swan Coastal Plain appears to have been buffered climatically during the Quaternary, with a hydrological regime similar to the present (Wyrwoll et al., 2014). In particular, Karri trees (Eucalyptus

This article is protected by copyright. All rights reserved. 
diversicolor) and other moisture sensitive plants in the far southwest of the region did not disappear despite arid conditions further inland. Historical changes in climate almost certainly occurred during the development of the chronosequences, but available evidence suggests that this was relatively moderate compared to the more substantial variation further inland (Wyrwoll et al. 2014). We assume, therefore, that the climate ranking of the four chronosequences from the drier north to wetter south has been maintained throughout their geological history.

Soil moisture and temperature regimes in Soil Taxonomy are defined by the control section between 30 and $90 \mathrm{~cm}$ in sandy textured soil (Soil Survey Staff, 1999). No soil temperature data were available for the chronosequences, so we estimated it from air temperatures at nearby stations. Mean annual air temperature varied between $15.2^{\circ} \mathrm{C}$ and $19.0^{\circ} \mathrm{C}$, and for all sequences the difference between the minimum and maximum mean monthly temperature is $>6^{\circ} \mathrm{C}$. Therefore, the soil temperature regime is thermic for all four chronosequences. Despite the marked variation in rainfall and potential evapotranspiration along the climate gradient, the four chronosequences are under a xeric moisture regime because the soil is dry for at least 45 days in summer, wet for at least 45 days in the winter and moist for more than half the year in total. The latter criterion is marginal at Jurien Bay where precipitation exceeds evapotranspiration for at least six months of the year. In the xeric moisture regime, rainfall is particularly effective for leaching because it occurs in winter when potential evapotranspiration is least.

This article is protected by copyright. All rights reserved. 


\section{Soil sampling}

A profile pit was excavated at each of six (Jurien Bay) or seven (all other chronosequences) stages along each chronosequence (Figure 2). The pits were on the shoulders or upper slopes of dunes, except for the stage- 6 profile where dune morphology was indistinct. Pits were at least 1-m deep, and up to 2-m deep on older dunes. Deeper soil was sampled by augering through the pit floor when necessary (up to 6-m deep). However, deep augering was often constrained by dry and incohesive sand, despite the use of a specially designed sand auger (Dormer Soil Samplers, Murwillumbah South, New South Wales, Australia) and frequent addition of water to the auger hole. We did not sample the thin, intermittent and seasonally variable litter layer $\left(\mathrm{O}_{\mathrm{i}}\right.$ horizon). Profiles were described according to Soil Taxonomy (Soil Survey Staff, 1999) and the Australian Soil Classification (Isbell, 2002), and samples were taken from each horizon for bulk density and laboratory analysis. Profile descriptions and analytical data are provided in full in the Supporting Information. Profile data for the Jurien Bay chronosequence is from Turner \& Laliberté (2015).

To quantify changes in nutrients that could limit biological activity, we sampled surface soil $(0-10$-cm depth) in eighty $10 \mathrm{~m} \times 10 \mathrm{~m}$ plots across the four chronosequences $(20$ plots per chronosequence). In each chronosequence, first we selected five chronosequence stages (stages 1, 2, 3, 4 and 6) that represented a strong gradient of nutrient availability and of the type and strength of nutrient limitation, based on previous research along the Jurien Bay chronosequence (Laliberté et al., 2012; Hayes et al., 2014; Turner \& Laliberté, 2015) and on 
previous soil analyses by McArthur (2004). We excluded the older Spearwood dunes (stages $5 \mathrm{a}$ and $5 \mathrm{~b}$ ) from the surface soil sampling because there is little variation in surface soil chemistry between older Spearwood and Bassendean soils (Turner \& Laliberté, 2015). For the Jurien Bay chronosequence, we randomly selected four existing plots (Laliberté et al., 2012; Hayes et al., 2014; Laliberté et al., 2014; Turner \& Laliberté, 2015; Zemunik et al., 2015). For the other three chronosequences, the four replicate sampling plots in each of the five chronosequence stages were placed randomly and at least $50 \mathrm{~m}$ apart near the profile pits to ensure that replicate plots followed the same dune. In each plot, we took four soil samples at $0-10-\mathrm{cm}$ depth with a 50-mm diameter sand auger, which were bulked and homogenized at plot level before chemical analyses. The homogenized samples were sieved $(<2 \mathrm{~mm})$ to remove roots and other large organic debris. Resin P was determined on fresh soil (see below) and the remaining soil was air-dried prior to further laboratory analyses.

\section{Soil analysis}

Soil analysis for profile pits and surface samples was identical to that described previously (Turner \& Laliberté, 2015). Briefly, soil pH was determined in both deionized water and 10 $\mathrm{mM} \mathrm{CaCl} 2$ in a 1:2 soil to solution ratio with a glass electrode. Sand $(53 \mu \mathrm{m}-2 \mathrm{~mm})$, silt (2 $\mu \mathrm{m}-53 \mu \mathrm{m})$ and clay $(<2 \mu \mathrm{m})$ sized particles were determined by the pipette method following pretreatment to remove soluble salts and organic matter (Gee \& Or, 2002), with further separation of sand fractions by manual dry sieving. Total carbon (C) and $\mathrm{N}$ were determined simultaneously by automated combustion and gas chromatography with thermal 
conductivity detection using a Thermo Flash 1112 elemental analyser (CE Elantech, Lakewood, NJ). Total $\mathrm{P}$ was determined by ignition $\left(550^{\circ} \mathrm{C}, 1\right.$ hour) and extraction in $1 \mathrm{M}$ $\mathrm{H}_{2} \mathrm{SO}_{4}$ (16 hours, 1:50 soil to solution ratio). This procedure provides a rapid approximation of total P, but can underestimate the true value in strongly weathered soil (Walker $\&$ Adams, 1958; Condron et al. 1990). Exchangeable cations were determined by extraction in $0.1 \mathrm{M}$ $\mathrm{BaCl}_{2}$ (2 hours, 1:30 soil to solution ratio) and detection by inductively-coupled plasma optical-emission spectrometry (ICP-OES) with an Optima 7300 DV (Perkin-Elmer Ltd, Shelton, CT) (Hendershot et al., 2008). Carbonate was determined by mass loss after addition of $3 \mathrm{M} \mathrm{HCl}$ (Loeppert \& Suarez, 1996) and organic C was calculated as the difference between total $\mathrm{C}$ and $\mathrm{CaCO}_{3}$-C. Bulk density was determined by taking three replicate cores of known volume per horizon with a $7.5-\mathrm{cm}$ diameter stainless steel ring and determining the soil mass after drying at $105^{\circ} \mathrm{C}$. Readily-exchangeable phosphate (resin P) was determined by extraction with anion exchange membranes (Turner \& Romero, 2009). Total exchangeable bases (TEB) was calculated as the sum of $\mathrm{Ca}, \mathrm{K}, \mathrm{Mg}$ and $\mathrm{Na}$; effective cation exchange capacity (ECEC) was calculated as the sum of the charge equivalents of $\mathrm{Al}, \mathrm{Ca}, \mathrm{Fe}, \mathrm{K}, \mathrm{Mg}$, Mn and Na; base saturation was calculated by $(\mathrm{TEB} / \mathrm{ECEC}) \times 100$.

\section{Leaf area index}

Leaf area index (LAI) was estimated in the same plots from which surface soil was collected with a portable plant canopy imager (CI-110, CID Bio-Science, Camas, WA, USA). We took four canopy images per plot, each separated by $7 \mathrm{~m}$. Images were taken with the camera as

This article is protected by copyright. All rights reserved. 
close to the ground surface as possible to include vegetation of low stature and processed with the built-in software. Leaf area index was calculated by the gap-fraction inversion procedure.

Statistical analyses

Differences in soil properties among chronosequence stages within each of the four chronosequences were tested using generalized least squares models with the nlme package in R (Pinheiro \& Bates, 2000). Model assumptions (i.e. residuals centered around zero with constant variance) were assessed visually and appropriate variance structures (e.g. different variances for each chronosequence stage) were specified in the models if they improved the fit determined by likelihood-ratio tests. This ensures that model assumptions are not violated and that parameter estimates for the fixed effects are trustworthy (Pinheiro \& Bates, 2000). We calculated $95 \%$ confidence intervals from final models with the effects package in $\mathrm{R}$ (Fox, 2003).

\section{Results}

Vegetation

Vegetation varies markedly along the climosequence, from low stature shrubland in the north to relatively tall eucalyptus forest in the south (Fig $3 a-d)$. This change in vegetation structure

This article is protected by copyright. All rights reserved. 
was reflected in the variation of LAI, for which maximum values increased from approximately 0.5 or less at Jurien Bay in the drier north to 1.5 at Warren Beach in the wetter south (Figure 3e). Within the sequences, LAI generally increased in the younger stages and declined in older stages; this was less clear for the relatively dry Jurien Bay chronosequence and most pronounced for the wet Warren Beach chronosequence.

\section{Pedogenesis along the chronosequences}

Pedogenesis along all chronosequences followed a similar pattern to that reported previously for Jurien Bay (Turner \& Laliberté, 2015). Young soils developed on Holocene dunes were greyish, yellowish or pale brown with weakly developed surface horizons enriched with organic matter overlying several metres of unweathered calcareous sand (see Supporting Information). All young soils contained carbonate, but carbonate concentrations in the beach sand and youngest soils were greatest at Jurien (e $\left.80 \% \mathrm{CaCO}_{3}\right)$, less at Guilderton and Yalgorup (> 40\%) and least at Warren (d5\%) (Table 2). This indicates a gradient of declining carbonate concentration in modern parent sand from north to south. Despite this, young soil was strongly or very strongly alkaline in all chronosequences (Table 2).

The soil across the four chronosequences contained $>90 \%$ sand (Table 2), predominantly fine, medium or coarse $(0.1-1.0 \mathrm{~mm})$, with few very fine or very coarse grains (Table $\mathrm{S} 1$, Supporting Information). Carbonate declined with pedogenesis in all chronosequences, and was absent from stage 4 profiles (Middle Pleistocene) above the indurated petrocalcic

This article is protected by copyright. All rights reserved. 
horizons (calcrete) where present. Carbonate depletion occurred earlier in the surface horizons of the two wetter sequences; it was evident in stage 2 profiles at Yalgorup and Warren (Table 2, Figure S1) and was almost completely leached from stage 3 (old Holocene) dunes at Warren.

With pedogenesis the soil begins to acidify, carbonate is progressively leached from the profiles and precipitated at depth, forming an indurated petrocalcic horizon beneath residual yellow sand characteristic of young Spearwood dunes (120 000 years old; stage 4). The soils have brownish yellow subsoil with $>95 \%$ residual quartz sand. The yellow colour derives from goethite and the weathering of minerals such as ilmenite, garnet, amphibole and epidote (Bastian, 1996). Continued pedogenesis leads to progressive leaching of iron oxides, sometimes forming a horizon dominated by illuvial iron oxides (Bs horizon), and leaving bleached quartz sand profiles several metres deep, characteristic of the Bassendean dunes (approximately 2 million years old; stage 6). The oldest soils have little cation exchange capacity, although base saturation remains large because extractable Al concentrations are small (Table 2). Although the organic horizon is typically limited to a thin layer of leaf litter at most sites, organic matter inputs seems sufficient to induce podzolization in the sandy soil with little buffering capacity.

The major pedogenic transitions were observed only weakly at Jurien Bay, but were reflected clearly in profiles at Guilderton and Yalgorup (Figure 4). In particular, the old Quindalup dunes (stage 3) at Guilderton had a calcic horizon with weakly cemented secondary 
carbonates and an incipient undulating petrocalcic horizon (Figure $4 \mathrm{c}-\mathrm{e}, 4 \mathrm{j}-\mathrm{k}$ ). In contrast, pedogenesis did not form a petrocalcic horizon at Warren, presumably because of the smaller carbonate content of the parent sand and greater leaching potential with the wetter climate. The old Spearwood dunes at Guilderton, Yalgorup and Warren included clear examples of the transition from Spearwood to Bassendean soils, with gradual leaching of iron oxides leading to the development of deep bleached eluvial (E) horizons over yellow sand (Figure $4 \mathrm{f}-\mathrm{i}, 41-n)$. Only the initial stage of this process was identified at Jurien, with a shallow incipient eluvial horizon in the oldest Spearwood dune.

\section{Soil Taxonomy}

Profiles along the four sequences did not qualify as Inceptisols in general because the particle-size classes were too coarse for cambic horizons (which require a texture of very fine sand or finer; Table 2). As at Jurien Bay, young soils (stages 1-3; Figure 4a-c) along the four sequences were classified as Psamments (Entisols) because of their coarse sandy texture. These young profiles were Quartzipsamments at Warren because of the nature of the sand, but Xeropsamments elsewhere (Table 2). The Xeropsamments were carbonatic, except for the youngest soil at Yalgorup where the carbonate content was marginally insufficient. The oldest Holocene soils at Guilderton and Yalgorup did not qualify as Inceptisols because the calcic horizons with free secondary carbonates were not within $100 \mathrm{~cm}$ of the soil surface. In the Australian Soil Classification (Isbell, 2002) the young Holocene soils are predominantly

This article is protected by copyright. All rights reserved. 
Shelly or Arenic Rudosols, whereas the old ones are Calcic or Petrocalcic Tenosols at Guilderton and Yalgorup, and Grey-Orthic Tenosols at Warren.

Middle and Early Pleistocene soils (stages 4-6; Figure 4f-i) were Quartzipsamments (Entisols) along the four sequences because their deep quartz sand profiles lack diagnostic horizons in the upper part of the profiles. The exceptions were the youngest Spearwood soils at Jurien and Yalgorup, which were Calcic Haploxerepts (Inceptisols) because of the petrocalcic horizon within $150 \mathrm{~cm}$ of the soil surface. The stage 4 profile at Guilderton was similar, but did not qualify as an Inceptisol because the petrocalcic horizon was $>150 \mathrm{~cm}$ below the soil surface. In the Australian Soil Classification the Middle Pleistocene soils are Grey or Yellow-Orthic Tenosols, with the younger profiles in the Petrocalcic Great Group and the older soils with a spodic horizon (stages $5 \mathrm{~b}$ and 6) being Sesquic or Humosesquic Aeric Podosols.

Soil from stage 6 (Fig 4i) was morphologically, chemically and physically similar along each of the four sequences. The designation of Entisols for these 2-million year profiles is an artifact of the Soil Taxonomy system, which does not consider parts of the profile deeper than $200 \mathrm{~cm}$ (Turner \& Laliberté, 2015). The same issue can occur with Quartzipsamments in Florida, USA, where it can lead to a landscape of alternating Spodosols and Entisols because the depth of the Bh horizon fluctuates around $200 \mathrm{~cm}$ (Harris et al., 2005). We observed a clear spodic horizon in Bassendean soil along the Yalgorup chronosequence only, although this indurated 'coffee rock' was too deep $(>200 \mathrm{~cm})$ for the profile to be placed in the 
Spodosols. However, an additional profile at Warren, not on the main chronosequence but on Bassendean sand, qualified as a Spodosol with a spodic horizon within $200 \mathrm{~cm}$ of the soil surface (see profile classifications in Supporting Information). Quartz-rich soils often contain insufficient metals to produce a spodic horizon and develop into Quartzipsamments (Fanning \& Fanning, 1989). Nevertheless, variation in the presence of a spodic horizon in the Swan Coastal Plain has been linked to differences in proximity to the water table (McArthur \& Russell 1978). In the absence of spodic horizons, the Bassendean profiles qualify as GreyOrthic-Tenesols in the Australian Soil Classification.

Organic carbon, total nitrogen, and total phosphorus

Profile-weighted organic $\mathrm{C}$ and $\mathrm{N}$ stocks followed a consistent pattern along chronosequences stages, but varied across the climosequence (Table 3, Figures S2, S3, Supporting Information). Stocks of both $\mathrm{C}$ and $\mathrm{N}$ tended to increase in the early stages of pedogenesis, reaching up to $12 \mathrm{~kg} \mathrm{C} \mathrm{m}^{-2}$ and $648.5 \mathrm{~g} \mathrm{~N} \mathrm{~m}^{-2}$ in the old Holocene dunes at Yalgorup, and then to decline to smaller amounts in older dunes (Table 3). Organic C was, however, noticeably large in the oldest soil at Guilderton $\left(9.8 \mathrm{~kg} \mathrm{C} \mathrm{m}^{-2}\right)$ compared to the earlier stages of the sequence.

Total P stocks in the youngest soil (stage 1) were greatest at Jurien $\left(300 \mathrm{~g} \mathrm{P} \mathrm{m}^{-2}\right)$, smaller at Guilderton and Yalgorup (210-240 $\left.\mathrm{g} \mathrm{P} \mathrm{m}^{-2}\right)$, and smallest at Warren $\left(36 \mathrm{~g} \mathrm{P} \mathrm{m}^{-2}\right)$, reflecting variation in the carbonate and $\mathrm{P}$ contents of the parent sand (Table 3, Figure 5). Total P

This article is protected by copyright. All rights reserved. 
declined more or less continuously throughout the chronosequences to very small amounts of $<5 \mathrm{~g} \mathrm{P} \mathrm{m}^{-2}$ in old Spearwood and Bassendean soils. An exception was the increase in total $\mathrm{P}$ concentration in the Holocene dunes at Yalgorup, probably because of the large primary productivity at this old site (reflected in the large organic C content).

In surface soil (0-10-cm depth) along the four sequences, organic $\mathrm{C}$ concentrations were smallest in the youngest chronosequence stage and then increased to the largest values in stage 2 or 3, except for Yalgorup where organic $\mathrm{C}$ was also large in the oldest Holocene stage (Figure 6a). There was a decline in organic $\mathrm{C}$ from stage 3 to 4 in three chronosequences (Jurien Bay, Guilderton and Yalgorup), whereas organic C remained constant from stage 3 to 4 in Warren (Figure 6a). Total nitrogen followed similar patterns to organic C (Figure 6b). Total $\mathrm{N}$ concentrations were initially small in all chronosequences, then reached maximum values in stage 2 (Jurien Bay) or stage 3 (all other chronosequences). Following this increase, there was a decline in total nitrogen from stage 3 or 4 in all chronosequences (Figure 6b). In the oldest soil (stage 6), total $\mathrm{N}$ concentrations were as small as stage 1 for all sequences except Yalgorup (Figure 6b).

In the three sequences from the Swan Coastal Plain (Jurien Bay, Guilderton, Yalgorup), there were large differences in total P concentrations between the Holocene dunes, which had relatively large concentrations, and the older stages, which had very small total $\mathrm{P}$ concentrations (Figure 6c). In contrast, total P concentrations in surface soil at Warren were much smaller in stage 1 , increased slightly to stage 4 , probably because of plants lifting 
nutrients to the topsoil and the concentration in organic matter at the surface (Laliberte et al., 2012; Turner \& Laliberté, 2015), then declined to very small concentrations in stage 6 (Figure 6c).

At all stages along the four chronosequences there was a clear increase in the proportion of total $\mathrm{P}$ present as organic $\mathrm{P}$ during pedogenesis; organic $\mathrm{P}$ was almost $100 \%$ of total $\mathrm{P}$ in the topsoil in stage 6 for the three wetter sequences (Guilderton, Yalgorup and Warren; Figure 6d). In general, organic $\mathrm{P}$ in topsoil represented a greater proportion of total $\mathrm{P}$ as the climate became cooler and wetter (i.e. from Jurien Bay to Warren; Figure 6d).

There were marked increases in topsoil N:P ratio from the youngest to oldest stage in all chronosequences (Figure 6e); it was eventually around 50 or more in the oldest stages. The increase in the N:P ratio was more pronounced in the three drier Swan Coastal Plain chronosequences, whereas at Warren it increased from stage 1 to 2 but then did not increase further in older soils (Figure 6e). Profile-weighted nutrient ratios demonstrated a similar pattern as in topsoil (Table 3; Figure S4, Supporting Information). Overall, C:N, C:P and N:P ratios increased continuously along all chronosequences, with the largest values on the oldest soils. For profile-weighted ratios, the largest values were a $\mathrm{C}: \mathrm{N}$ ratio of 51.4, C:P ratio of 3764 and N:P ratio of 73.2 in the oldest profile at Guilderton.

Surface soil pH, exchangeable phosphorus and exchangeable cations

This article is protected by copyright. All rights reserved. 
Surface soils in all four chronosequence stages were initially alkaline $(\mathrm{pH}>7$ in $0.01 \mathrm{M}$ $\mathrm{CaCl}_{2}$ ), but then gradually acidified during pedogenesis (Figure 7a). Some young soils were strongly alkaline ( $\mathrm{pH}>9$ in water); such values have been reported previously for comparable dunes nearby (McArthur, 2004) and presumably reflect the predominance of sodium carbonate over calcium carbonate, although we did not measure this. Soil $\mathrm{pH}$ in surface soils in stage 1 decreased from the driest to the wettest sequence (i.e. Jurien Bay $>$ Guilderton $>$ Yalgorup $>$ Warren), reflecting the decline in carbonate concentration of the beach sand from Jurien Bay to Warren (Table 2). Similarly, soil pH in the oldest stages was higher at Jurien than in the other sequences.

Resin P concentrations were largest in the youngest soil of the three drier chronosequences and then declined continuously with pedogenesis to the smallest values on the oldest soil (Figure $7 b$ ). In contrast, resin $\mathrm{P}$ concentrations at Warren increased with pedogenesis in Holocene dunes, then declined on Middle and Early Pleistocene dunes (Figure 7b). Overall, resin P concentrations on the oldest dunes were smaller at the driest site (Jurien Bay).

In all chronosequences, effective cation exchange capacity (ECEC) declined in the oldest soil to very small values (Figure 7c). However, changes in ECEC during the first three stages differed among chronosequences. In Jurien Bay, and in Guilderton to a lesser degree, there was a general decline in ECEC from the youngest to the oldest soil (Figure 7c). By contrast, in Yalgorup and Warren there were increases in ECEC from stages 1 to 3 before the decline in the older soil (Figure 7c). At all stages of the four chronosequences, ECEC was dominated 
largely by $\mathrm{Ca}$ irrespective of soil age, and $\mathrm{Mg}$ was the second most important exchangeable cation (Figure 7c). In contrast, concentrations of other exchangeable cations (Al, Fe, K, Mn, $\mathrm{Na}$ ) were very small (Figure 7c). The large ECEC of young soil probably reflects extraction of $\mathrm{Ca}$ from carbonates. Base saturation was $>90 \%$ in surface soils throughout the four sequences; it was $<100 \%$ only in Pleistocene soils (Figure 7d).

\section{Discussion}

The four long-term chronosequences that form a climosequence of chronosequences in southwestern Australia is exceptional because of its Mediterranean climate and location in a global biodiversity hotspot (Hopper \& Gioia, 2004), making it particularly valuable for understanding edaphic controls over plant species distributions (e.g. Laliberté et al., 2014; Zemunik et al., 2016). These chronosequences enable examination of the effect of climate on patterns of pedogenesis and nutrient status during long-term ecosystem development. Such climate $\times$ age systems are rare worldwide: the only comparable framework that we are aware of is on the Hawaiian Islands where steep rainfall gradients, well-constrained parent material and uniform vegetation allow unparalleled control of soil forming factors (Vitousek, 2004).

Despite relatively large variation in climate, pedogenic change has been remarkably consistent along the four chronosequences, with decalcification in Holocene dunes and leaching of iron oxides from Middle Pleistocene dunes resulting in bleached quartz sand profiles several metres deep on Early Pleistocene dunes. These transitions are reflected in the 
profiles along the chronosequences, providing evidence that soil variation in the sandplains has resulted from in situ soil development. In particular, profiles show the formation of calcic and petrocalcic horizons resulting from carbonate leaching, and the development of deep eluvial horizons with the leaching of iron oxides from quartz grains.

Changes in plant-available nutrients during ecosystem development were also consistent along the four chronosequences: $\mathrm{N}$ concentrations increased in young soils, $\mathrm{P}$ concentrations and exchangeable cations declined in old soils and N:P ratios increased throughout ecosystem development. This pattern of nutrients availability corresponds closely with the Walker \& Syers (1976) model of nutrient transformations during pedogenesis. Despite clear effects on vegetation structure (reflected by changes in LAI), climate effects on nutrients in soil appeared marginal; the only clear variation with climate was in the nature of the soil P pools. Specifically, the proportion of organic forms of $\mathrm{P}$ was greater and increased earlier in ecosystem development at wetter sites, whereas resin P concentrations were also greater in old Holocene and Middle Pleistocene dunes at the wettest site. These differences suggest that greater plant biomass or productivity maintains $\mathrm{P}$ in actively cycling pools, and therefore might buffer against nutrient loss by leaching (Porder \& Chadwick, 2009).

Vitousek \& Chadwick (2013) describe 'soil process domains', in which soil properties change relatively little despite variation in rainfall. These domains occur between 'pedogenic thresholds' where soil properties change rapidly across a relatively small change in rainfall. They identified four domains for Andisols about 150000 years old on Hawaii: (i) a low 
rainfall domain where evapotranspiration exceeds precipitation and carbonate precipitation dominates, (ii) an intermediate domain where biological uplift of nutrients buffers against loss by leaching, (iii) a high rainfall domain where leaching losses dominate and (iv) a very wet domain where saturation causes iron to be solubilized and lost by reduction and leaching. The intermediate rainfall domain on Hawaii occurs between about 700 and $1700 \mathrm{~mm}$, and based on the results for our Australian climosequence the four chronosequences appear to occupy a single process domain. Patterns of nutrient availability and pedogenesis are similar across the entire climosequence; precipitation exceeds potential evapotranspiration at the most southerly site only, and there only marginally $(52 \mathrm{~mm})$. The lack of variation in base cations with climate is probably related in part to the sandy nature of the soils, with limited formation of clays or secondary minerals following decalcification. Soil $\mathrm{pH}$ and $\mathrm{Ca}$ concentrations decline in young soil associated with the depletion of carbonates and exchangeable $\mathrm{Al}$ occurs in trace concentrations, therefore base saturation is always large despite small concentrations of base cations. Once carbonates are depleted from Holocene soil, and iron oxide coatings leached from the Middle Pleistocene soil, there is essentially no cation exchange capacity other than on organic matter.

Vegetation structure varied markedly along the climosequence and within chronosequences. Along the climosequence, vegetation changed from low-stature shrubs in the drier north to relatively tall Eucalyptus forest in the wetter south. Changes in fertility with increasing soil age appear quite constant across the four chronosequences, so the overall increase in biomass and LAI with increasing rainfall is probably related to water availability. The patterns in 
vegetation along the chronosequences (i.e. during ecosystem development) were consistent with the concept of retrogression (Wardle et al., 2004; Peltzer et al., 2010); LAI increased in in the early stages of pedogenesis and then declined in the oldest soil with strong P limitation. This trend was most clear along the wetter chronosequences, where maximum LAI also occurred earlier in ecosystem development and least clear in the driest chronosequence where there was no consistent trend in LAI along the chronosequence. Ecosystem retrogression therefore appears to be expressed more strongly in the vegetation structure along wetter chronosequences.

Variation in expression of strong $\mathrm{P}$ limitation on the plant community might be affected by corresponding variation in plant community diversity. Although we have not yet conducted detailed vegetation assessments along the four chronosequences (but see Zemunik et al., 2015; 2016), our field observations indicate declining diversity with increasing rainfall from the hyperdiverse shrubland at Jurien Bay (Laliberté et al., 2014; Zemunik et al., 2016) to the comparatively low diversity forest at Warren Beach (Hopper \& Gioia, 2004). Kitayama (2005) proposed that ecosystem retrogression is less likely in diverse plant communities such as lowland tropical forests because there are probably species that can maintain productivity on soil with little P. For example, the response of the vegetation to changes in nutrient status linked to long-term pedogenesis is clear along the Hawaiian Island chronosequence where forests are dominated by a single species of tree (Vitousek \& Farrington, 1997). In contrast, strongly weathered soils at Jurien Bay support a diverse array of species that show high P-use efficiency and can maintain relatively large biomass (Hayes et al., 2014; Lambers et al., 
2015; Zemunik et al., 2015). For example, the oldest soils are dominated by slow-growing plant species with long-lived leaves that contain little $\mathrm{P}$ and resorb it efficiently prior to abscission (Hayes et al., 2014). Considerable regional plant diversity might therefore buffer against a decline in productivity related to the long-term decline in $\mathrm{P}$ availability during retrogression (Vitousek, 2004).

There are two caveats concerning the chronosequences. First, there is variation in the parent sand along the coastline with smaller carbonate concentrations (and therefore total $\mathrm{P}$ concentrations) towards the wetter south. The regional variation in the chemical composition of beach sand presumably reflects differences in offshore productivity (McArthur, 2004), but we do not know whether the pattern in modern sand composition also occurred historically. Despite the variation in carbonate, however, $\mathrm{pH}$ remains well-constrained across the climosequence. Second, there are consistent patterns of soil development along the four chronosequences, but we have not yet been able to precisely quantify dune ages and therefore rates of soil development, despite attempts at luminescence dating. However, the dune ages are relatively well constrained, particularly for the Swan Coastal Plain (see also Turner \& Laliberté, 2015), which provides confidence that the overall patterns are consistent among the four chronosequences. In the Spearwood dunes, Bastian (1996) recognized five stages, although at least seven sea level high-stands are recognized. The 120000 -year high-stand (Marine Isotope Stage 5e) can be readily identified and is consistent among our chronosequences, whereas a 200 000-year high-stand was relatively small and likely to have been overridden by the subsequent 120 000-year event. Before that, high-stands occurred at 
approximately $220000,240000,280000,330000$ and 410000 years. Therefore, it is likely that Spearwood stages 4 and 5a in our sequences are separated by at least 100000 years, but that stages $5 \mathrm{a}$ and $5 \mathrm{~b}$ could be separated by as few as 20000 years or as many as 190000 years.

\section{Conclusion}

A series of four long-term retrogressive chronosequences across a clear climate gradient in southwestern Australia provides an important model system for studying long-term soil and ecosystem development, particularly given that well-characterized retrogressive sequences are rare worldwide. These four sequences should be particularly valuable because they provide strong natural gradients of soil fertility to explore plant adaptations to declining nutrient availability and edaphic drivers of plant and microbial diversity under contrasting climates. They can also be used to examine the independent influence of climate on aboveand below-ground organisms while controlling for variation in soil nutrients.

\section{Supporting Information}

Supporting information is available in the online version of this paper. Profile descriptions and data for the chronosequence at Jurien Bay were published previously and are available online: http://link.springer.com/article/10.1007/s10021-014-9830-0\#SupplementaryMaterial

This article is protected by copyright. All rights reserved. 
Table S1. Profile-weighted size distribution of the sand fraction (\% of total sand $0.05-2.00$ $\mathrm{mm}$ ) according to the USDA classification system in seven stages along the Guilderton, Yalgorup and Warren chronosequences, southwestern Australia.

Figure S1. Profile-weighted concentrations of carbonate to $100-\mathrm{cm}$ depth along the four dune chronosequences: (a) Jurien Bay, (b) Guilderton, (c) Yalgorup and (d) Warren.

Figure S2. Profile-weighted concentrations of organic carbon to $100-\mathrm{cm}$ depth along the four dune chronosequences: (a) Jurien Bay, (b) Guilderton, (c) Yalgorup and (d) Warren.

Figure S3. Profile-weighted concentrations of total nitrogen to $100-\mathrm{cm}$ depth along the four dune chronosequences: (a) Jurien Bay, (b) Guilderton, (c) Yalgorup and (d) Warren.

Figure S4. Changes in soil (a) organic carbon to total nitrogen $(\mathrm{C}: \mathrm{N})$ and $(\mathrm{b})$ organic carbon to total phosphorus $(\mathrm{C}: \mathrm{P})$ ratios in surface soils $(0-10 \mathrm{~cm}$ depth) across the four chronosequences.

Profile descriptions and photographs for the Guilderton Chronosequence.

Profile descriptions and photographs for the Yalgorup Chronosequence.

Profile descriptions and photographs for the Warren Chronosequence.

This article is protected by copyright. All rights reserved. 
An excel file contains full data for profiles from the Guilderton, Yalgorup, and Warren Chronosequences.

\section{Acknowledgements}

Funding was provided by a Discovery Early Career Researcher Award (DE120100352) and a Discovery Project (DP130100016) from the Australian Research Council, a Research Collaboration Award from The University of Western Australia to EL and BLT and a NSERC Discovery Grant awarded to EL. The authors thank Dayana Agudo, Aleksandra Bielnicka and Paola Escobar for laboratory support, and Felipe Albornoz, Hans Lambers, Kenny Png, François Teste, Karl-Heinz Wyrwoll and Graham Zemunik for assistance in the field. Figure 2 was created from base maps provided by the Department of Agriculture and Food of Western Australia.

\section{References}

Bastian, L.V. 1996. Residual soil mineralogy and dune subdivision, Swan Coastal Plain, Western Australia. Australian Journal of Earth Sciences, 43, 31-44.

Chadwick, O.A. \& Chorover, J. 2001. The chemistry of pedogenic thresholds. Geoderma, 100, 321-353.

This article is protected by copyright. All rights reserved. 
Chadwick, O.A., Gavenda, R.T., Kelly, E.F., Ziegler, K., Olson, C.G., Elliott, W.C. \& Hendricks, D.M. 2003. The impact of climate on the biogeochemical functioning of volcanic soils. Chemical Geology, 202, 195-223.

Condron, L.M., Moir, J.O., Tiessen, H. \& Stewart, J.W.B. 1990. Critical evaluation of methods for determining total organic phosphorus in tropical soils. Soil Science Society American Journal, 54, 1261-1266.

Fanning, D.S. \& Fanning, M.C.B. 1989. Soil Morphology, Genesis and Classification. John Wiley \& Sons, New York, NY.

Feng, J., Turner, B.L., Lü, X., Chen, Z., Wei, K., Tian, J. et al. 2016. Phosphorus transformations along a large-scale climosequence in arid and semiarid grasslands of northern China. Global Biogeochemical Cycles, 30, 1264-1275.

Fox, J. 2003. Effect displays in R for generalised linear models. Journal of Statistical Software 8, 1-27.

Fujioka, T., Chappell, J., Fifield, L.K. \& Rhodes, E.J. 2009. Australian desert dune fields initiated with Pliocene-Pleistocene global climatic shift. Geology, 37, 51-54.

Gee, G.W. \& Or, D. 2002. Particle size analysis. In: Methods of Soil Analysis, Part 4 Physical Methods (eds J.H. Dane \& C. Topp), pp. 255-293. Soil Science Society of America, Madison, WI.

Harris, W.G., Crownover, S.H. \& Hinchee, J. 2005. Problems arising from fixed-depth assessment of deeply weathered sandy soils. Geoderma, 126, 161-165.

This article is protected by copyright. All rights reserved. 
Hayes, P., Turner, B.L., Lambers, H. \& Laliberté, E. 2014. Foliar nutrient concentrations and resorption efficiency in plants of contrasting nutrient-acquisition strategies along a 2-millionyear dune chronosequence. Journal of Ecology, 102, 396-410.

Hendershot, W.H., Lalande, H. \& Duquette, M. 2008. Chapter 18. Ion exchange and exchangeable cations. In: Soil Sampling and Methods of Analysis (eds M.R. Carter \& E. Gregorich), pp. 173-178. Canadian Society of Soil Science and CRC Press, Boca Raton, FL. Hopper, S.D. \& Gioia, P. 2004. The Southwest Australian Floristic Region: Evolution and conservation of a global hot spot of biodiversity. Annual Review of Ecology, Evolution, and Systematics, 35, 623-650.

Hothorn, T., Bretz, F., \& Westfall, P. 2008. Simultaneous inference in general parametric models. Biometrical Journal 50, 346-363.

Isbell, R.F. 2002. The Australian Soil Classification, Revised Edition. CSIRO Publishing, Collingwood, Victoria, Australia.

Jangid, K., Whitman, W.B., Condron, L.M., Turner, B.L. \& Williams, M.A. 2013. Soil bacterial community succession during long-term ecosystem development. Molecular Ecology, 22, 3415-3424.

Kendrick, G.W., Wyrwoll, K.-H. \& Szabo, B.J. 1991. Pliocene-Pleistocene coastal events and history along the western margin of Australia. Quaternary Science Reviews, 10, 419-439. Kitayama, K. 2005. Comment on "Ecosystem properties and forest decline in contrasting long-term chronosequences". Science, 308, 633.

This article is protected by copyright. All rights reserved. 
Laliberté, E., Grace, J.B., Huston, M.A., Lambers, H., Teste, F.P., Turner, B.L. \& Wardle, D.A. 2013. How does pedogenesis drive plant diversity? Trends in Ecology \& Evolution, 28, $331-340$.

Laliberté, E., Turner, B.L., Costes, T., Pearse, S.J., Wyrwoll, K.-H., Zemunik, G. \& Lambers, H. 2012. Experimental assessment of nutrient limitation along a 2-million-year dune chronosequence in the south-western Australia biodiversity hotspot. Journal of Ecology, 100, $631-642$.

Laliberté, E., Zemunik, G. \& Turner, B.L. 2014. Environmental filtering explains variation in plant diversity along resource gradients. Science, 345, 1602-1605.

Laliberté, E., Kardol, P., Didham, R.K., Teste, F.P., Turner, B.L. \& Wardle, D. A. 2017. Soil fertility shapes belowground food webs across a regional climate gradient. Ecology Letters 20, $1273-1284$.

Lambers, H., Clode, P.L., Hawkins, H.-J., Laliberté, E., Oliveira, R.S., Reddell, P. et al. 2015. Metabolic adaptations of the non-mycotrophic Proteaceae to soils with low phosphorus availability. In: Annual Plant Reviews Volume 48 (ed. W.C. Plaxton \& H. Lambers), pp. 289335. John Wiley \& Sons, Chichester.

Loeppert, R.H. \& Suarez, D.L. 1996. Carbonate and Gypsum. In: Methods of Soil Analysis, Part 3 Chemical Methods (ed. D.L.E.A. Sparks), pp. 437-474. Soil Science Society of America Madison, WI.

McArthur, W.M. 2004. Reference Soils of South-western Australia. Department of Agriculture (WA), Perth, Australia.

This article is protected by copyright. All rights reserved. 
McArthur, W.M. \& Bettenay, E. 1974. Development and Distribution of Soils of the Swan Coastal Plain, Western Australia. CSIRO, Melbourne, Australia.

Peltzer, D.A., Wardle, D.A., Allison, V.J., Baisden, W.T., Bardgett, R.D., Chadwick, O.A. et al. 2010. Understanding ecosystem retrogression. Ecological Monographs, 80, 509-529. Pinheiro, J.C. \& Bates, D.M. 2000. Mixed-Effects Models in S and S-PLUS. Springer, New York, USA.

Playford, P.E., Cockbain, A.E. \& Lowe, G.H. 1976. Geology of the Perth Basin, Western Australia; Bulletin 124 of the Geological Survey of Western Australia. Geological Survey of Western Australia, Perth, Australia.

Porder, S. \& Chadwick, O.A. 2009. Climate and soil-age constraints on nutrient uplift and retention by plants. Ecology, 90, 623-636.

Purdie, B., Tille, P. \& Schoknecht, N. 2004. Soil-landscape Mapping in South-Western Australia An Overview of Methodology and Outputs. Department of Agriculture and Food, Western Australia, Perth, Australia.

Selmants, P.C. \& Hart, S.C. 2010. Phosphorus and soil developement: Does the Walker and Syers model apply to semiarid ecosystems? Ecology, 91, 474-484.

Soil Survey Staff. 1999. Soil Taxonomy: A Basic System of Soil Classification for Making and Interpreting Soil Surveys. United States Department of Agriculture-Natural Resources Conservation Service, Lincoln, NE.

Turner, B.L. \& Laliberté, E. 2015. Soil development and nutrient availability along a 2 million-year coastal dune chronosequence under species-rich Mediterranean shrubland in southwestern Australia. Ecosystems, 18, 287-309.

This article is protected by copyright. All rights reserved. 
Turner, B.L. \& Romero, T.E. 2009. Short-term changes in extractable inorganic nutrients during storage of tropical rain forest soils. Soil Science Society of America Journal, 73, 19721979.

Vitousek, P.M. 2004. Nutrient Cycling and Limitation. Princeton University Press, Princeton, New Jersey.

Vitousek, P.M. \& Chadwick, O.A. 2013. Pedogenic thresholds and soil process domains in basalt-derived soils. Ecosystems, 16, 1379-1395.

Vitousek, P.M. \& Farrington, H. 1997. Nutrient limitation and soil development:

Experimental test of a biogeochemical theory. Biogeochemistry, 37, 63-75.

Walker, T.W. \& Adams, A.F.R. 1958. Studies on soil organic matter: I. Influence of phosphorus content of parent materials on accumulations of carbon, nitrogen, sulfur, and organic phosphorus in grassland soils. Soil Science, 85, 307-318.

Walker, T.W. \& Syers, J.K. 1976. The fate of phosphorus during pedogenesis. Geoderma, 15, $1-19$.

Wardle, D.A., Walker, L.R. \& Bardgett, R.D. 2004. Ecosystem properties and forest decline in contrasting long-term chronosequences. Science, 305, 509-513.

Williamson, W.M., Wardle, D.A. \& Yeates, G.W. 2005. Changes in soil microbial and nematode communities during ecosystem decline across a long-term chronosequence. Soil Biology \& Biochemistry, 37, 1289-1301.

Wyrwoll, K.-H., Turner, B.L. \& Findlater, P. 2014. On the origins, geomorphology and soils of the sandplains of south-western Australia. In: Plant Life on the Sandplains in Southwest

This article is protected by copyright. All rights reserved. 
Australia, a Global Biodiversity Hotspot (ed. H. Lambers). University of Western Australia, Crawley, Australia.

Zemunik, G., Turner, B.L., Lambers, H. \& Laliberté, E. 2015. Diversity of plant nutrientacquisition strategies increases during long-term ecosystem development. Nature Plants, $\mathbf{1}$, doi:10.1038/nplants.2015.50.

Zemunik, G., Turner, B.L., Lambers, H. \& Laliberté, E. 2016. Increasing plant species diversity and extreme species turnover accompany declining soil fertility along a long-term chronosequence in a biodiversity hotspot. Journal of Ecology, 104, 792-805.

Zheng, H., Wyrwoll, K.-H., Li, Z. \& Powell, C.M. 1998. Onset of aridity in southern Western Australia - a preliminary palaeomagnetic appraisal. Global and Planetary Change, 18, 175187.

This article is protected by copyright. All rights reserved. 


\section{Figure Legends}

Figure 1. (a) Location of the study area in southwestern Australia, (b) map of southwestern Australia showing isolines for annual rainfall $\left(\mathrm{mm} \mathrm{year}^{-1}\right)$ and locations of the four dune chronosequences (rainfall data are averages from the period 1961-1990 (www.bom.gov.au)) and (c) monthly climate data, including precipitation, potential evapotranspiration and mean temperature for each chronosequence.

Figure 2. Detailed soil classification maps showing the location of the soil sampling sites along the four dune chronosequences: (a) Jurien Bay, (b) Guilderton, (c) Yalgorup and (d) Warren. Mapping of soil systems and subsystems is based on the Western Australian Department of Agriculture soil classification.

Figure 3. Changes in vegetation at the oldest chronosequence stage (i.e. stage 6) for each of the four chronosequences, (a) Jurien Bay, (b) Guilderton, (c) Yalgorup, (d) Warren and (e) the leaf area index (LAI) along the four dune chronosequences. Leaf area index was not measured for chronosequence stages $5 \mathrm{a}$ and $5 \mathrm{~b}$. Bar heights represent means $(n=4)$ and error bars represent 95\% confidence intervals. Photographic credits: P. Kardol, E. Laliberté, F. Teste, B. Turner.

Figure 4. Soil development along the Guilderton chronosequence: (a) young Holocene dune ( 100 years, stage 1), (b) medium-aged Holocene dune with incipient A horizon $(\sim 1000$

This article is protected by copyright. All rights reserved. 
years, stage 2), (c) old Holocene dune (6500 years, stage 3), (d) precipitation of pedogenic carbonate forming a calcic horizon in old Holocene dune, (e) surface of a petrocalcic horizon in old Holocene dune, (f) young Middle Pleistocene dune showing decalcified sand coated with iron oxides (120 000 years, stage 4), (g) medium-aged Middle Pleistocene dune with incipient E horizon ( 250 000 years, stage 5a), (h) old Middle Pleistocene dune with 1-m deep bleached E horizon ( 400 000 years, stage 5b), (i) Early Pleistocene dune showing bleached quartz sand ( $\sim 2$ million years, stage 6$)$. Fine detail in the subsoil of five profiles showing key pedogenic stages: (j) a mixture of carbonate and quartz sand-sized grains in young Holocene dune, (k) sand grains cemented by pedogenic carbonate at $150-\mathrm{cm}$ depth in old Holocene dune, (1) iron oxide coatings on quartz grains in young Middle Pleistocene dune, (m) quartz grains cemented by iron oxide at 250-cm depth in old Middle Pleistocene dune and (n) clean quartz grains leached of iron oxides in Early Pleistocene dune.

Figure 5. Profile-weighted contents of total $P$ to $100-\mathrm{cm}$ depth along the four dune chronosequences: (a) Jurien Bay, (b) Guilderton, (c) Yalgorup and (d) Warren. Note the differences in the $x$-axis values among chronosequences.

Figure 6. Changes in (a) organic $\mathrm{C}$, (b) total $\mathrm{N}$, (c) total $\mathrm{P}$, (d) proportion of total $\mathrm{P}$ present as organic $\mathrm{P}$ and (e) total $\mathrm{N}$ : total $\mathrm{P}$ ratio, in surface soils (0-10-cm depth) across the four chronosequences. Bar heights represent means $(n=4)$ and error bars represent $95 \%$ confidence intervals.

This article is protected by copyright. All rights reserved. 
Figure 7. Changes in (a) $\mathrm{pH}$ (measured in $0.01 \mathrm{M} \mathrm{CaCl}_{2}$ ), (b) resin-extractable $\mathrm{P}$, (c) exchangeable cations and effective cation exchange capacity (ECEC) and (d) base saturation in surface soils (0-10-cm depth) across the four chronosequences. Points (in panels a and d) or bar heights (in panels b and c) represent means $(n=4)$ and error bars represent $95 \%$ confidence intervals.

This article is protected by copyright. All rights reserved. 
Table 1. Climate at four long-term chronosequences in southwestern Australia.

\begin{tabular}{|c|c|c|c|c|c|c|c|c|c|}
\hline Chronosequence $^{\mathrm{a}}$ & $\begin{array}{l}\text { Mean annual } \\
\text { temperature } \\
/{ }^{\circ} \mathrm{C}^{\mathrm{b}} \text { (Range) }\end{array}$ & $\begin{array}{l}\text { Average mean } \\
\text { monthly } \\
\text { minimum } \\
\text { temperature } \\
/{ }^{\circ} \mathrm{C}^{\mathrm{d}} \text { (Range) }\end{array}$ & $\begin{array}{l}\text { Average mean } \\
\text { monthly } \\
\text { maximum } \\
\text { temperature } \\
/{ }^{\circ} \mathrm{C}^{\mathrm{e}} \text { (Range) }\end{array}$ & $\begin{array}{l}\text { Mean annual } \\
\text { precipitation } \\
\text { / mm }\end{array}$ & $\begin{array}{l}\text { Potential } \\
\text { annual } \\
\text { evapotranspir } \\
\text { ation } / \mathrm{mm}^{\mathrm{c}}\end{array}$ & $\begin{array}{l}\text { Water } \\
\text { balance } \\
/ \mathrm{mm}^{-1} \\
\text { year }^{-1}\end{array}$ & Dry season ${ }^{f}$ & $\begin{array}{l}\text { Dry season } \\
\text { rainfall / } \mathrm{mm}\end{array}$ & $\begin{array}{l}\text { Rainfall } \\
\text { November to } \\
\text { April / mm }\end{array}$ \\
\hline Jurien Bay & $\begin{array}{l}19.0(13.1, \\
24.9)\end{array}$ & $\begin{array}{l}14.4(9.3, \\
18.0)\end{array}$ & $\begin{array}{l}24.5(19.5, \\
30.9)\end{array}$ & 533.2 & 1433 & -900 & $\begin{array}{l}\text { October to } \\
\text { April }\end{array}$ & $\begin{array}{l}116.2(21.8 \% \\
\text { of total) }\end{array}$ & $\begin{array}{l}89.6(16.8 \% \\
\text { of total) }\end{array}$ \\
\hline Guilderton & $\begin{array}{l}18.4(11.1, \\
25.6)\end{array}$ & $\begin{array}{l}12.3(6.2, \\
17.1)\end{array}$ & $\begin{array}{l}25.2(18.3, \\
33.3)\end{array}$ & 653.4 & 1403 & -750 & $\begin{array}{l}\text { November } \\
\text { to April }\end{array}$ & $\begin{array}{l}97.1(14.9 \% \\
\text { of total) }\end{array}$ & $\begin{array}{l}97.1(14.9 \% \\
\text { of total) }\end{array}$ \\
\hline Yalgorup & $\begin{array}{l}17.3(11.5, \\
23.1)\end{array}$ & $\begin{array}{l}12.3(7.9 \\
16.1)\end{array}$ & $\begin{array}{l}23.6(16.7, \\
31.0)\end{array}$ & 943.0 & 1300 & -357 & $\begin{array}{l}\text { December } \\
\text { to March }\end{array}$ & $\begin{array}{l}65.1(6.9 \% \\
\text { of total) }\end{array}$ & $\begin{array}{l}153.7(16.3 \% \\
\text { of total) }\end{array}$ \\
\hline Warren & $\begin{array}{l}15.2(10.1, \\
20.3)\end{array}$ & $\begin{array}{l}11.1(7.1, \\
13.7)\end{array}$ & $\begin{array}{l}20.1(15.1, \\
26.5)\end{array}$ & 1184.9 & 1133 & 52 & $\begin{array}{l}\text { January to } \\
\text { February }\end{array}$ & $\begin{array}{l}40.4(3.4 \% \\
\text { of total) }\end{array}$ & $\begin{array}{l}247.7(20.9 \% \\
\text { of total) }\end{array}$ \\
\hline
\end{tabular}

${ }^{a}$ Data from the following Bureau of Meteorology stations: Jurien Bay (009131; 1968-2015), Guilderton Aerodrome (009178; 1996-2015) located 36.6 km from Guilderton, Wokalup (009642; 1951-2015) located 34.7 km from Preston Beach, Pemberton (009592; 1941-2015) located 19 km from Warren Beach.

${ }^{\mathrm{b}}$ Range in mean monthly temperatures in parentheses. The lowest value is typically between July and August, and the highest value between January and February.

${ }^{c}$ Calculated from monthly values from Bureau of Meteorology maps.

${ }^{\mathrm{d}}$ Range in mean monthly minimum temperatures in parentheses.

${ }^{\mathrm{e}}$ Range in mean monthly maximum temperatures in parentheses. 
${ }^{\mathrm{f}}$ Defined as months receiving $<30 \mathrm{~mm}$ rainfall, inclusive of stated months. 
Table 2. Chronosequence stages, taxonomic classes and features, and profile-weighted soil physical and chemical properties for soils along the Jurien Bay, Guilderton, Yalgorup and Warren chronosequences, southwestern Australia

\begin{tabular}{|c|c|c|c|c|c|c|c|c|c|}
\hline $\begin{array}{l}\text { Chronoseque } \\
\text { nce stage }\end{array}$ & Soil Taxonomy & $\begin{array}{l}\text { Carbon } \\
\text { ate } / \%\end{array}$ & $\begin{array}{l}\text { Sand }^{a} \\
/ \%\end{array}$ & $\begin{array}{l}\text { Silt } \\
/ \%\end{array}$ & $\begin{array}{l}\text { Clay } \\
/ \%\end{array}$ & $\begin{array}{l}\mathrm{pH} \\
\left(\mathrm{H}_{2} \mathrm{O}\right)\end{array}$ & $\begin{array}{l}\mathrm{pH} \\
\left(\mathrm{CaCl}_{2}\right)\end{array}$ & $\begin{array}{l}\text { ECEC } \\
/ \mathrm{cmol}_{\mathrm{c}} \mathrm{kg}^{-1}\end{array}$ & $\begin{array}{l}\text { Base } \\
\text { sat. /\% }\end{array}$ \\
\hline \multicolumn{10}{|l|}{ Jurien Bay ${ }^{b}$} \\
\hline 1 & Carbonatic, thermic, Typic Xeropsamments & 82 & 98.2 & 1.1 & 0.7 & 9.1 & 8.2 & 12.93 & 100.0 \\
\hline 2 & Carbonatic, thermic, Typic Xeropsamments & 66 & 95.9 & 2.1 & 2.0 & 9.2 & 8.1 & 5.52 & 99.9 \\
\hline 3 & Siliceous, thermic, Typic Xeropsamments & 25 & 96.9 & 1.4 & 1.6 & 8.9 & 8.0 & 5.01 & 99.4 \\
\hline 4 & Sandy, siliceous, thermic, Calcic Haploxerepts & 0 & 94.0 & 2.9 & 3.1 & 6.9 & 6.1 & 1.94 & 100.0 \\
\hline 5 & Thermic, Xeric Quartzipsamments & 0 & 96.7 & 1.3 & 2.0 & 6.8 & 5.7 & 0.96 & 99.9 \\
\hline 6 & Thermic, Xeric Quartzipsamments & 0 & 97.3 & 2.3 & 0.3 & 5.6 & 4.4 & 0.98 & 97.4 \\
\hline \multicolumn{10}{|l|}{ Guilderton } \\
\hline 1 & Carbonatic, thermic, Typic Xeropsamments & 45 & 98.6 & 0.1 & 1.3 & 9.0 & 7.5 & 15.12 & 100.0 \\
\hline 2 & Carbonatic, thermic, Typic Xeropsamments & 49 & 97.7 & 0.7 & 1.5 & 9.1 & 7.7 & 3.04 & 100.0 \\
\hline 3 & Carbonatic, thermic, Typic Xeropsamments & 38 & 92.3 & 2.3 & 5.4 & 8.7 & 7.3 & 5.15 & 100.0 \\
\hline 4 & Thermic, uncoated, Xeric Quartzipsamments & 0 & 93.5 & 2.3 & 4.2 & 6.0 & 5.2 & 0.43 & 98.6 \\
\hline $5 a$ & Thermic, uncoated, Xeric Quartzipsamments & 0 & 95.1 & 1.5 & 3.4 & 5.7 & 4.8 & 0.19 & 87.3 \\
\hline $5 b$ & Thermic, uncoated Xeric Quartzipsamments & 0 & 98.5 & 0.7 & 0.9 & 5.5 & 4.7 & 0.11 & 85.6 \\
\hline 6 & Thermic, uncoated, Xeric Quartzipsamments & 0 & 98.6 & 0.6 & 0.8 & 5.6 & 3.8 & 0.68 & 100.0 \\
\hline \multicolumn{10}{|l|}{ Yalgorup } \\
\hline 1 & Mixed, thermic, Typic Xeropsamments & 37 & 98.4 & 0.6 & 1.0 & 8.6 & 6.9 & 3.08 & 100.0 \\
\hline 2 & Carbonatic, thermic, Typic Xeropsamments & 48 & 96.8 & 0.4 & 2.8 & 8.6 & 7.5 & 3.98 & 99.8 \\
\hline 3 & Carbonatic, thermic, Typic Xeropsamments & 42 & 94.0 & 1.5 & 4.5 & 8.9 & 7.6 & 7.21 & 99.9 \\
\hline 4 & Sandy, siliceous, thermic, Calcic Haploxerepts & 0 & 97.4 & 1.2 & 1.3 & 6.8 & 6.3 & 1.13 & 98.7 \\
\hline $5 a$ & Thermic, uncoated, Xeric Quartzipsamments & 0 & 96.5 & 2.0 & 1.5 & 6.2 & 5.0 & 0.44 & 91.5 \\
\hline $5 b$ & Thermic, uncoated, Xeric Quartzipsamments & 0 & 98.0 & 1.1 & 0.9 & 5.9 & 4.2 & 0.16 & 84.0 \\
\hline 6 & Thermic, uncoated, Xeric Quartzipsamments & 0 & 97.1 & 2.4 & 0.5 & 5.9 & 4.1 & 0.30 & 94.3 \\
\hline \multicolumn{10}{|l|}{ Warren } \\
\hline 1 & Thermic, uncoated, Xeric Quartzipsamments & 2.7 & 99.1 & 0.5 & 0.4 & 9.2 & 8.1 & 3.79 & 99.9 \\
\hline 2 & Thermic, uncoated, Xeric Quartzipsamments & 1.5 & 99.1 & 0.3 & 0.6 & 9.0 & 8.1 & 2.36 & 100.0 \\
\hline 3 & Thermic, uncoated, Xeric Quartzipsamments & 0.2 & 97.8 & 1.7 & 0.5 & 6.2 & 5.3 & 1.05 & 93.5 \\
\hline 4 & Thermic, uncoated, Xeric Quartzipsamments & 0 & 98.9 & 0.6 & 0.5 & 5.8 & 4.9 & 0.35 & 80.1 \\
\hline $5 a$ & Thermic, uncoated, Xeric Quartzipsamments & 0 & 98.9 & 0.6 & 0.6 & 5.9 & 4.7 & 0.51 & 94.4 \\
\hline $5 b$ & Thermic, uncoated, Xeric Quartzipsamments & 0 & 98.9 & 0.6 & 0.5 & 5.3 & 4.2 & 0.68 & 97.2 \\
\hline 6 & Thermic, uncoated, Xeric Quartzipsamments & 0 & 98.8 & 0.7 & 0.5 & 5.3 & 4.0 & 0.27 & 94.9 \\
\hline
\end{tabular}

${ }^{a}$ Data on sand size distribution is presented in Table S1, Supporting Information.

${ }^{\mathrm{b}}$ Data on Jurien Bay profiles from Turner \& Laliberté (2015)

ECEC, effective cation exchange capacity; Base sat., base saturation. 
Table 3. Profile-weighted nutrient concentrations for the upper $100 \mathrm{~cm}$ of soil in profile pits along the Jurien Bay, Guilderton, Yalgorup and Warren chronosequences, southwestern Australia. Data for the Jurien Bay chronosequence are from Turner \& Laliberté (2015).

\begin{tabular}{|c|c|c|c|c|c|c|}
\hline $\begin{array}{l}\text { Chronosequence } \\
\text { stage }\end{array}$ & $\begin{array}{l}\text { Organic C } \\
/ \mathrm{g} \mathrm{m}^{-2}\end{array}$ & $\begin{array}{l}\text { Total N } \\
/ \mathrm{g} \mathrm{m}^{-2}\end{array}$ & $\begin{array}{l}\text { Total P } \\
/ \mathrm{g} \mathrm{m}^{-2} \\
\end{array}$ & $\mathrm{C}: \mathrm{N}$ & $C: P$ & $\mathrm{~N}: \mathrm{P}$ \\
\hline \multicolumn{7}{|l|}{ Jurien Bay } \\
\hline 1 & 8900 & 495.5 & 384.3 & 18.0 & 23.2 & 1.3 \\
\hline 2 & 14678 & 763.3 & 346.4 & 19.2 & 42.4 & 2.2 \\
\hline 3 & 17720 & 362.2 & 194.8 & 48.9 & 90.9 & 1.9 \\
\hline 4 & 3864 & 166.5 & 28.8 & 23.2 & 134.4 & 5.8 \\
\hline 5 & 2917 & 119.2 & 12.7 & 24.5 & 228.9 & 9.4 \\
\hline 6 & 4063 & 117.8 & 6.4 & 34.5 & 639.2 & 18.5 \\
\hline \multicolumn{7}{|l|}{ Guilderton } \\
\hline 1 & 2165 & 223.3 & 240.1 & 9.7 & 9.0 & 0.9 \\
\hline 2 & 4284 & 371.4 & 136.3 & 11.5 & 31.4 & 2.7 \\
\hline 3 & 7282 & 537.7 & 198.5 & 13.5 & 36.7 & 2.7 \\
\hline 4 & 1500 & 110.8 & 14.5 & 13.5 & 103.3 & 7.1 \\
\hline $5 a$ & 1924 & 102.0 & 10.9 & 18.9 & 177.2 & 9.4 \\
\hline $5 b$ & 1772 & 54.3 & 3.1 & 32.6 & 565.6 & 17.3 \\
\hline 6 & 9801 & 190.7 & 2.6 & 51.4 & 3764.4 & 73.2 \\
\hline \multicolumn{7}{|l|}{ Yalgorup } \\
\hline 1 & 3324 & 224.5 & 210.0 & 14.8 & 15.8 & 1.1 \\
\hline 2 & 6030 & 503.0 & 219.5 & 12.0 & 27.5 & 2.3 \\
\hline 3 & 12162 & 648.6 & 277.7 & 18.7 & 43.8 & 2.3 \\
\hline 4 & 4922 & 200.8 & 31.4 & 24.5 & 156.9 & 6.4 \\
\hline $5 a$ & 3336 & 117.5 & 6.6 & 28.4 & 508.7 & 17.9 \\
\hline $5 b$ & 6153 & 151.8 & 4.3 & 40.5 & 1434.8 & 35.4 \\
\hline 6 & 5430 & 181.0 & 5.6 & 30.0 & 976.7 & 32.6 \\
\hline \multicolumn{7}{|l|}{ Warren } \\
\hline 1 & 1891 & 88.0 & 35.6 & 21.5 & 53.1 & 2.5 \\
\hline 2 & 2055 & 145.7 & 23.0 & 14.1 & 89.2 & 6.3 \\
\hline 3 & 3337 & 239.5 & 18.4 & 13.9 & 181.4 & 13.0 \\
\hline 4 & 1925 & 99.4 & 11.4 & 19.4 & 169.5 & 8.8 \\
\hline $5 a$ & 2820 & 148.3 & 4.4 & 19.0 & 636.3 & 33.5 \\
\hline $5 b$ & 3932 & 140.2 & 4.5 & 28.0 & 869.0 & 31.0 \\
\hline 6 & 2675 & 74.1 & 2.3 & 36.1 & 1141.1 & 31.6 \\
\hline
\end{tabular}

This article is protected by copyright. All rights reserved. 


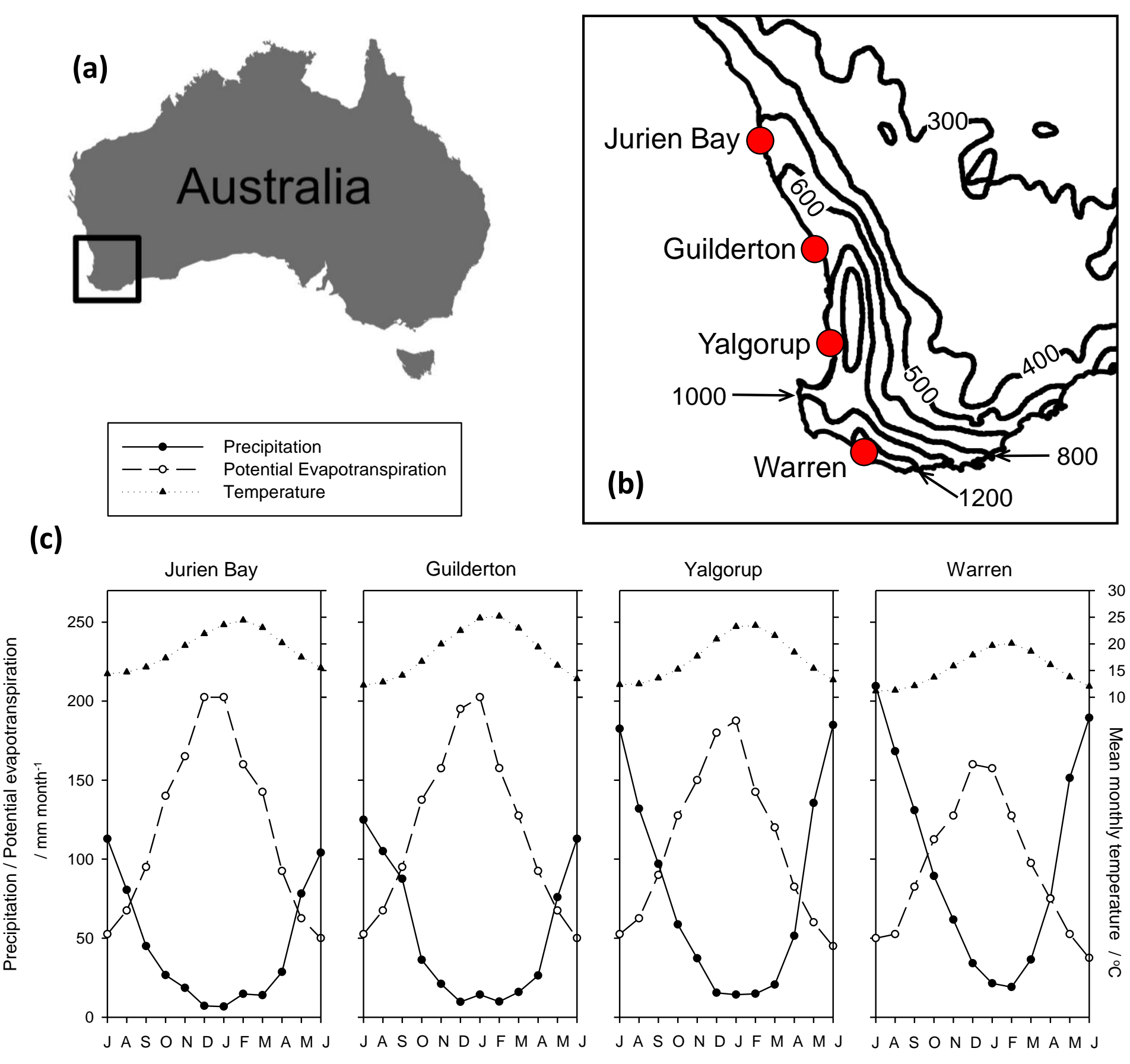

This article is protected by copyright. All rights reserved. 
(a)

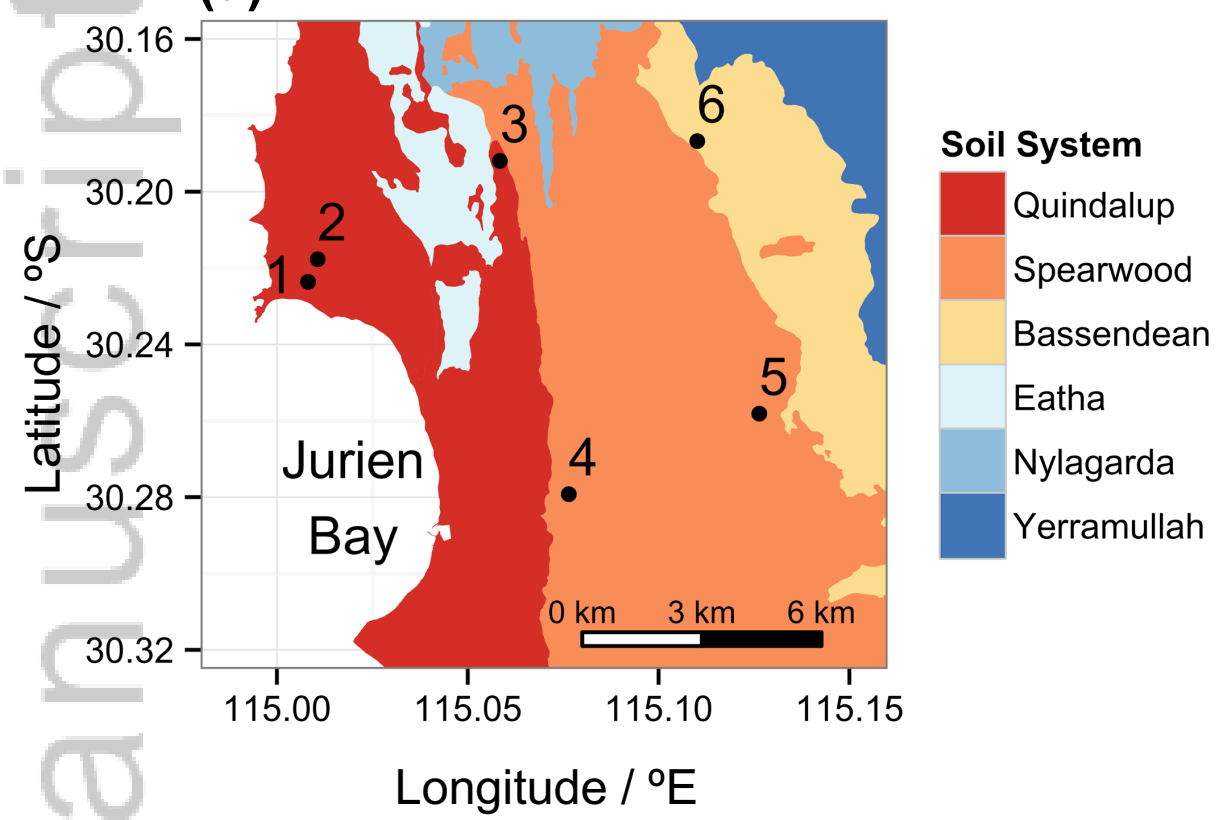

(c)

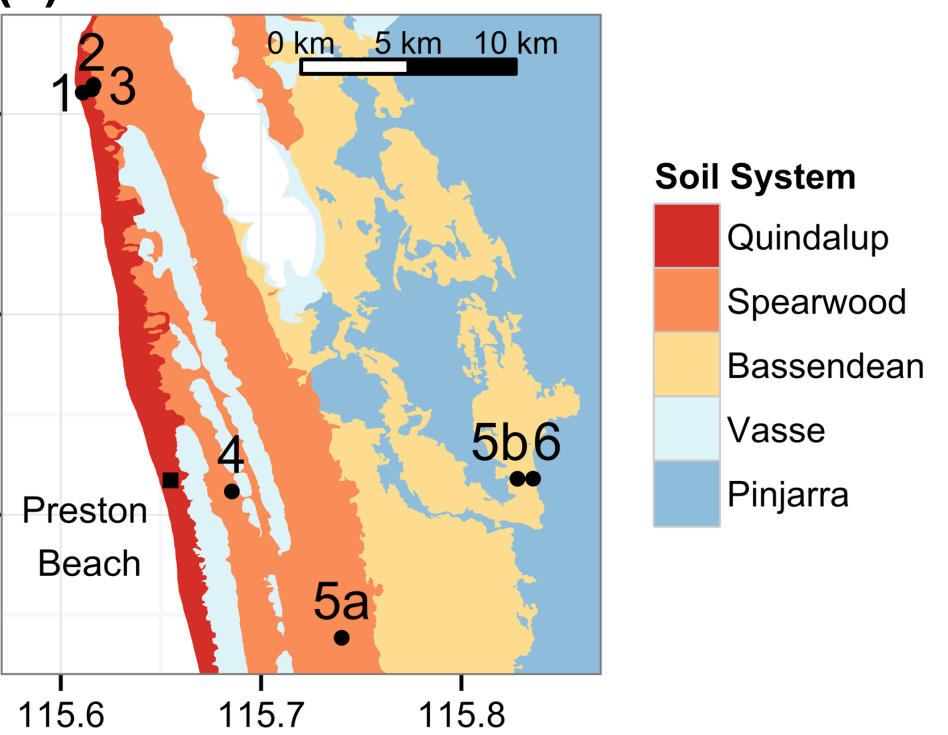
This article is protected by copyright. All rights reserved.
Longitude / ${ }^{\circ}$. (b)

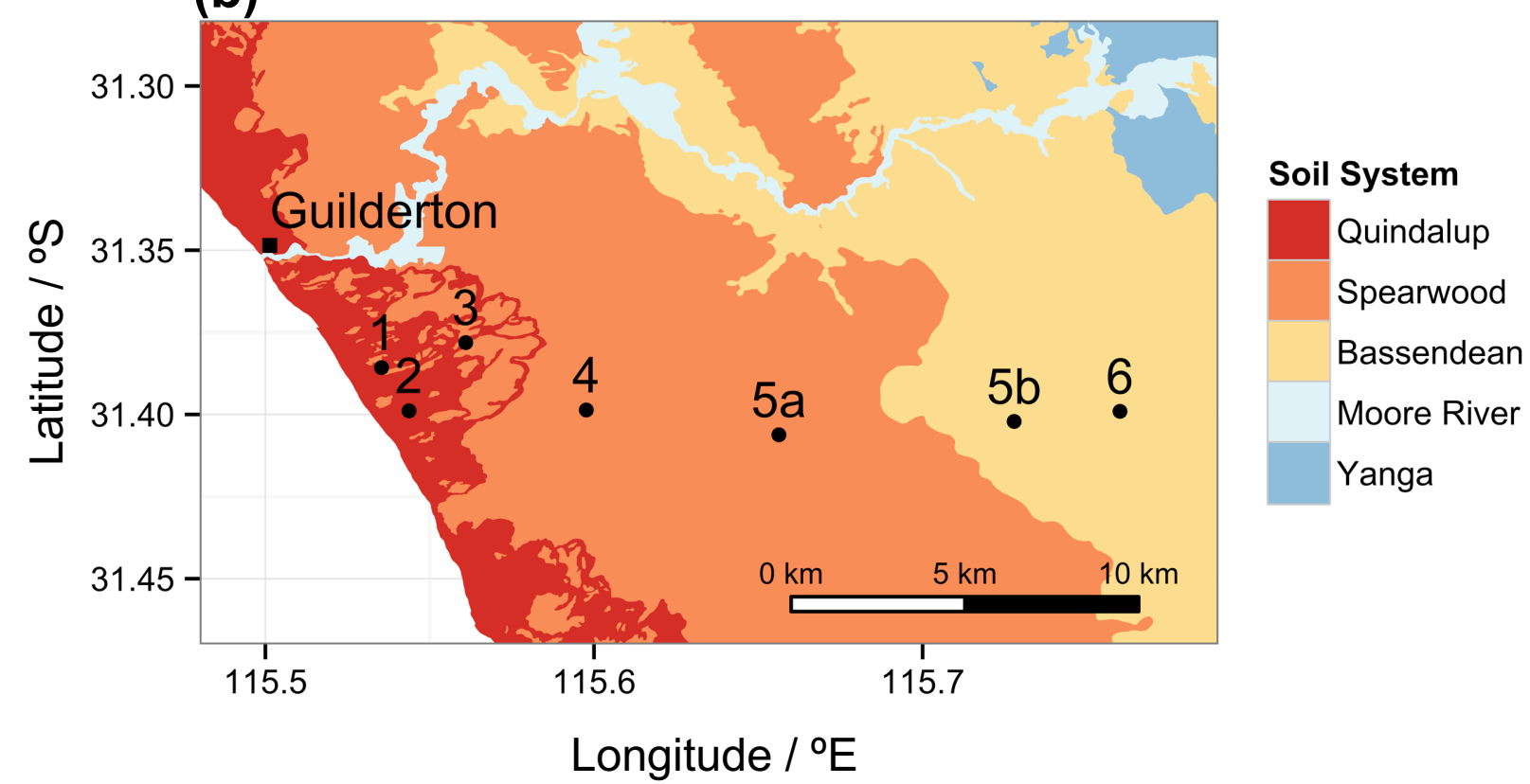


(a) Jurien Bay

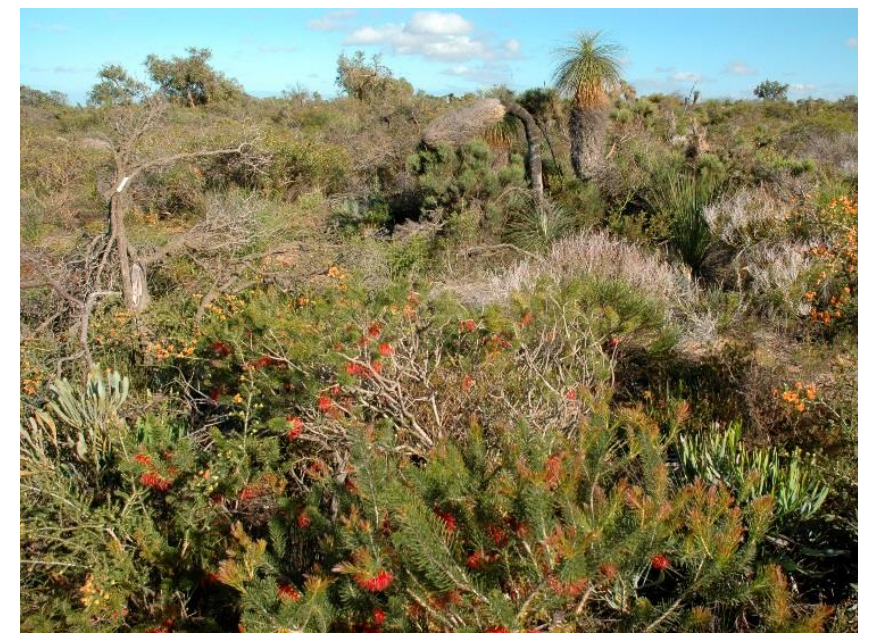

(c) Yalgorup

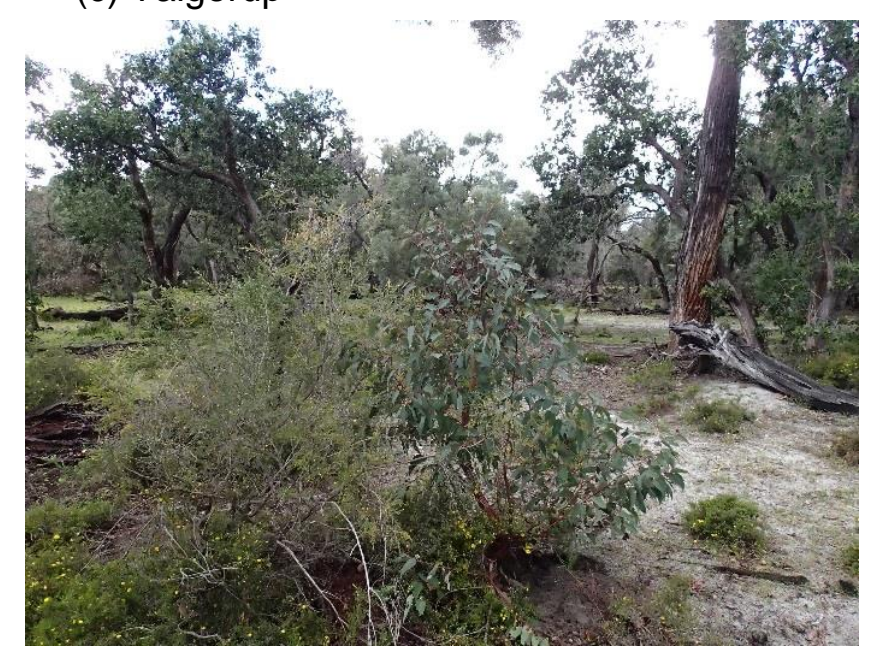

(e)

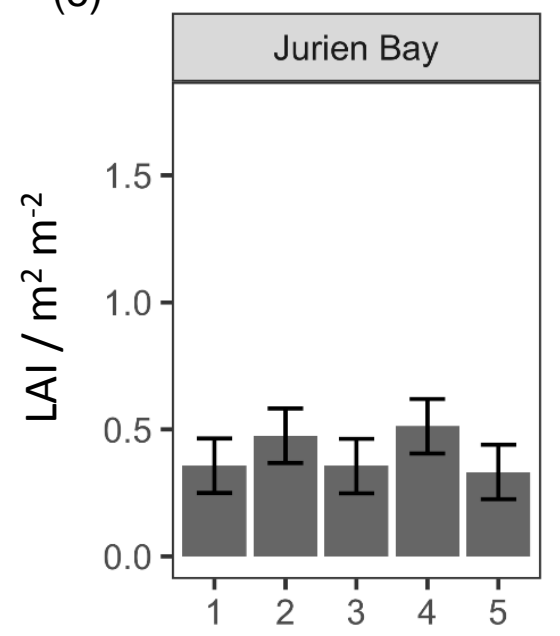

(b) Guilderton

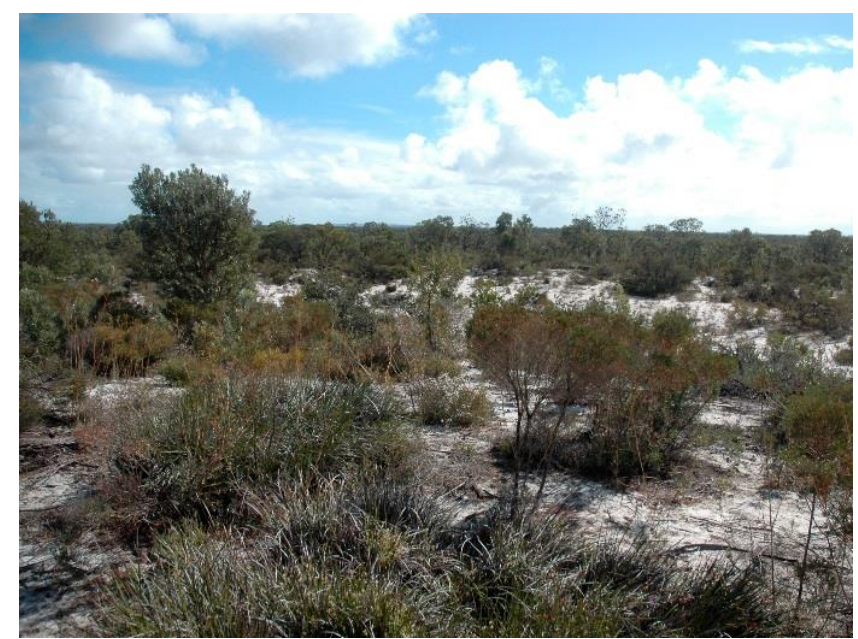

(d) Warren

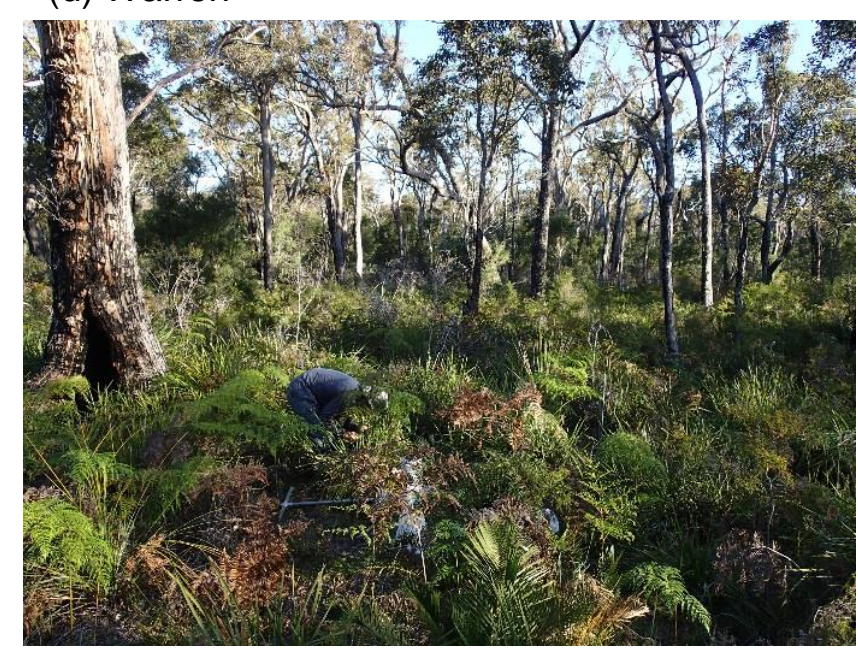

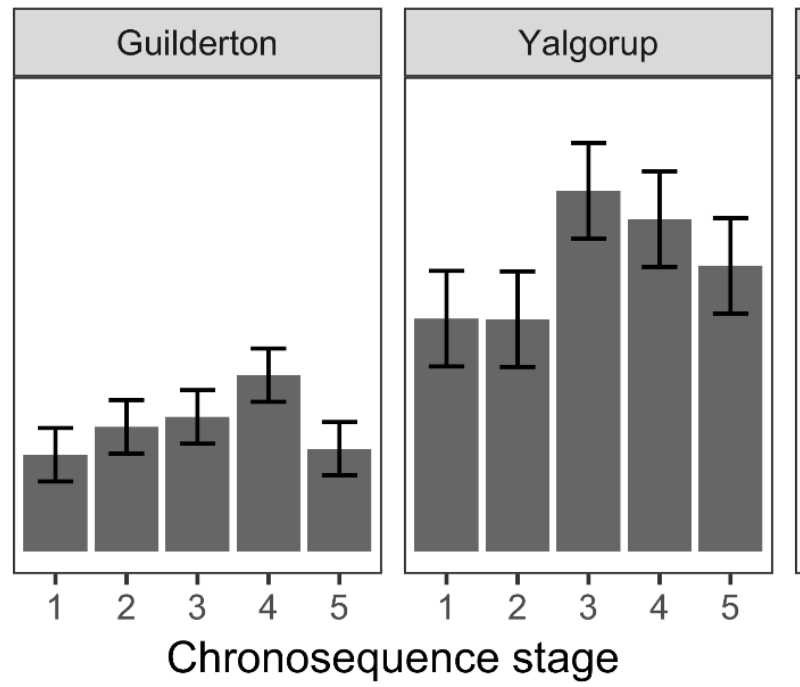

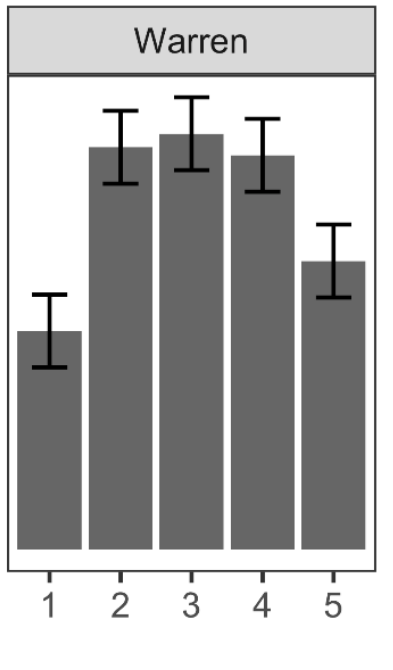

This article is protected by copyright. All rights reserved. 


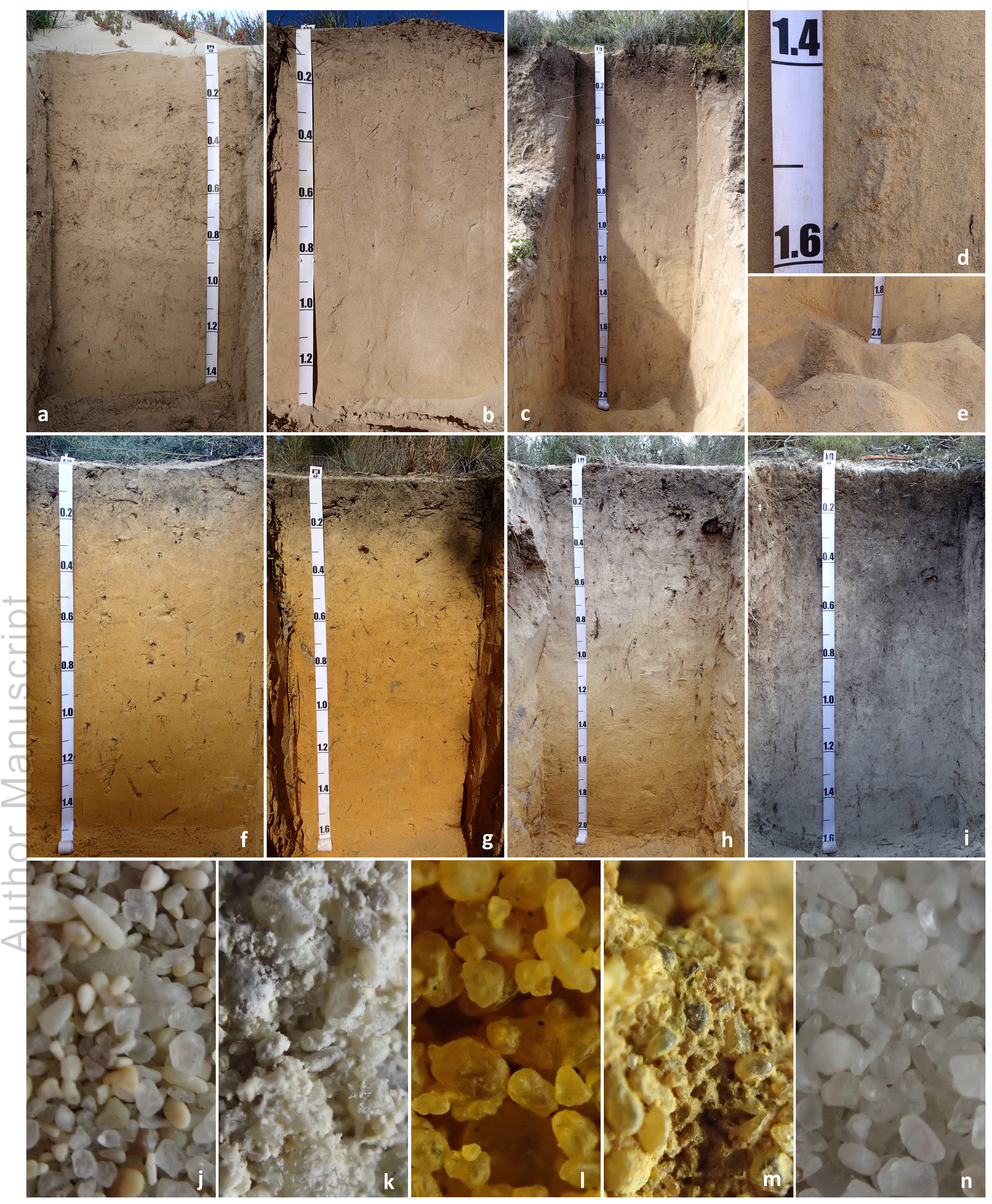


